Discussion Paper No. 10-079

\title{
Pollution Exposure and Infant Health: Evidence from Germany
}

Katja Coneus and C. Katharina Spiess

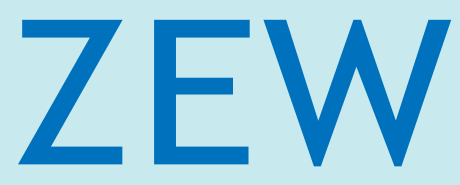

Zentrum für Europäische Wirtschaftsforschung $\mathrm{GmbH}$

Centre for European

Economic Research 
Discussion Paper No. 10-079

\title{
Pollution Exposure and Infant Health: Evidence from Germany
}

\author{
Katja Coneus and C. Katharina Spiess
}

Download this ZEW Discussion Paper from our ftp server:

ftp://ftp.zew.de/pub/zew-docs/dp/dp10079.pdf

Die Discussion Papers dienen einer möglichst schnellen Verbreitung von neueren Forschungsarbeiten des ZEW. Die Beiträge liegen in alleiniger Verantwortung der Autoren und stellen nicht notwendigerweise die Meinung des ZEW dar.

Discussion Papers are intended to make results of ZEW research promptly available to other economists in order to encourage discussion and suggestions for revisions. The authors are solely responsible for the contents which do not necessarily represent the opinion of the ZEW. 


\section{Non-technial summary}

Almost all western industrializ ed count ries have int roduced $\mathrm{s}$ ome measures for pollution abatement that ar e supposed to promote health . Our analys is focuses on the impact of pollution expos ure on infant health, bec ause particularly $c$ hildren are very sensitive to pollution. As a child's metabolism is regulated differently than that of an adult, it needs, relatively speaking, more energy and oxygen. Children $t$ ake in relatively more food per kilogram and $t$ herefore relatively more pollutants. Furthermore, they breathe relatively more pe $r$ kilogram of their bodyweight and, as a result, the respiratory tract is stressed more by pollutants.

We examine the impact of outdoor and indoor pollution on children's health from birth until the age of three years in Germany. Therefore, we use representative data from the German Socio-Ec onomic Panel (SOEP), co mbined with five air pollution levels. These dat a are provided by the Federal Environment Agency and cover the years 2002-2007. We obs erve five different pollutants ( $\mathrm{CO}, \mathrm{NO}_{2}, \mathrm{SO}_{2}, \mathrm{O}_{3}$, and $\left.\mathrm{PM}_{10}\right)$ on a (half-) hourly basis. We are able to follow the effect of pollution exposure on a child 's health during the fir st three years of life, accounting for time-invariant and unobserved neighbourhood-specific and mother-specific characteristics.

Our results suggest a significantly negativ e impact for some pollutants on infant health during early $\mathrm{c}$ hildhood. In comparis on to outdoor pollutio $\mathrm{n}$, indoor pollution seems to be more harmful directly after birth, while the relations hip between indoor and outdoor pollution changes later in chil dhood. Since smoking is one s ource of producing carbon monoxide and thus affects child health negatively, our results further support the advice to par ents of young children not to smoke. Moreover, the results underline the efforts made on the regional and national level t o reduce pollution levels. As pollution lev els are higher in urban areas, environmental policies should foc us particularly on reducing pollutant $s$ in these areas in order to improve child health. 


\section{Das Wichtigste in Kürze}

In Deutschland hat sich die Luftqualität seit den 90er Jahren zwar deutlich verbessert. Dennoch stellen hohe Luftschadstoffwerte ein Problem für die Gesundheit dar, insbesondere für die Gesundheit von Kinde rn. Im Vergleic $\mathrm{h}$ zu Erwachsenen geht der Stoffwechsel bei Kinder $\mathrm{n}$ deutlich sc hneller vons tatten, so dass Kinder relativ betrachtet (pro Kilogramm) meh $r$ Atemluft und mehr Nahrung zu sich nehmen, und somit Schadstoffen in stärkerem Maße ausgesetzt sind.

In dieser Studie unter suchen wir den Einfluss von Luft schadstoffen sowohl in Innenals auch in Außenräumen auf die Gesundheit von Kindern in den ersten drei Lebensjahren in Deutschland. Datengrundlagen daf ür sind das Sozio-oekonomische Panel (SOEP) und die Luftschadstoffwerte des Bundesumweltamtes für den Zeitraum 2002-2007. Betrachtet werden die zent ralen fünf Luftschadstoffe $\mathrm{CO}, \mathrm{NO}_{2}, \mathrm{SO}_{2}, \mathrm{O}_{3}$, and $\mathrm{PM}_{10}$, welche das Bundesumweltamt zur Messung der Luftqualität halbstü ndlich erfasst.

Unsere Ergebniss e zeigen, das s Schadstoffe sowohl in Inne $\mathrm{n}$ - als auc $\mathrm{h}$ in Außenräumen negativ signif ikant mit der $\mathrm{Ge}$ sundheit der Kinder zusammenhängen. Bei differenzierter Betrachtung zeigt sich, dass die Raumluftbelastung besonders schädlich für die Gesundheit unmittelbar nach der Geburt ist. Luftschadstoffe im Freien hingegen sind besonders schädlich für die kindliche Gesundheit im Alter von 2-3 Jahren. Da ins besondere der Verkehr und das Rauchen für di e Produktion von CO verantwortlich sind und dies er Schadstoff wie derum die Gesundheit b eeinträchtigt, könnte eine stärkere Kontrolle dieser Sc hadstoffquellen zur Verbesserung der kindlichen Gesundheit beitragen. 
Pollution Exposure and Infant Health:

Evidence from Germany

\title{
Katja Coneus
}

Centre for European Economic Research (ZEW Mannheim)

\author{
P.O.Box 103443 \\ 68034 Mannheim \\ Germany
}

Email: coneus@zew.de

Tel: +49621 1235-293

Fax: +49 621 1235-225

\section{Katharina Spiess}

(corresponding author)

German Institute for Economic Research (DIW Berlin), and Free University Berlin

DIW Berlin

Mohrenstrasse 58

10117 Berlin

Germany

Email:kspiess@diw.de

Tel: +49 30 89789-254

Fax: +49 30 89789-109

September 2010 


\begin{abstract}
:
This paper examines the impact of outdoor and indoor pollution on children's health from birth until the age of three years in Germany. We use representative data from the German Socio-Economic Panel (SOEP), combined with five air pollution levels. These data come from the Federal Environment Agency and cover the years 2002-2007. Our work offers three important contributions. Firstly, we use accurate measures for five different pollutants (CO, $\mathrm{NO}_{2}, \mathrm{SO}_{2}, \mathrm{O}_{3}$, and $\mathrm{PM}_{10}$ ) on a (half-)hourly basis. Secondly, we are able to follow the effect of pollution exposure on a child's health during the first three years of life, accounting for time-invariant and unobserved neighborhood and mother-specific characteristics. Thirdly, we calculate different pollution intensity measures. Instead of relying solely on mean pollution levels, we are able to use (half-)hourly pollution levels as well as indoor pollution as measurements for the total latent pollution exposure. Our results suggest a significantly negative impact for some pollutants on infant health during early childhood. In comparison to outdoor pollution, indoor pollution seems to be more harmful directly after birth, while the relationship between indoor and outdoor pollution changes later in childhood. Since smoking is one source of producing carbon monoxide and thus affects child health negatively, our results further support the advice to parents of young children not to smoke.
\end{abstract}

$J E L: \mathrm{I} 12, \mathrm{Q} 53, \mathrm{~J} 13$

Keywords: indoor and outdoor pollution, health, early childhood

\title{
Acknowledgement:
}

This paper profited substantially from the support of Tobia Lakes and Maria Brückner from the Geomatics Department at the Institute of Geography, Humboldt University Berlin. Without their help in calculating distances from homes to the next monitor station, this paper would not exist. We also thank Janet Currie and Johannes Schmieder for their invaluable comments during a research stay at Columbia University in 2009. Elisabeth Bügelmeyer and Eric Dubiel provided very useful research assistance. 


\section{Introduction}

Almost all western industrialized countries have introduced some measures for pollution abatement. These measures are often justified as something that will promote health. Although there is still much to learn about their effects and the mechanisms underlying them, it is often argued that the effects of air pollution on the health of adults tend to be long term and those on child health more short term. Our analyses focus on air pollution and child health. The link between air pollution and child health is of particular interest because children are very sensitive to pollution. As a child's metabolism is regulated differently than that of an adult, it needs, relatively speaking, more energy and oxygen. Children take in relatively more food per kilogram and therefore relatively more pollutants. Furthermore, they breathe relatively more per kilogram of their bodyweight and, as a result, the respiratory tract is stressed more by pollutants. Moreover, in the case of infant death, for instance, the link between cause and effect is immediate, whereas for adults diseases today may reflect pollution exposure that occurred many years ago. In addition to this, there is increasing evidence of long-term effects of poor infant health on future outcomes (see Currie 2009).

In the economic literature, there are some studies for the U.S. which focus on air pollution and child health (see Section 2). However, there is little evidence from other industrialized countries with different measures of pollution abatement. ${ }^{1}$ Here we focus on Germany, a country traditionally with a strong climate policy. The Federal Environment Agency (Bundesumweltamt) in Germany is responsible for pollution measurement. For this purpose, Germany is covered by a network of stations that regularly measure pollution. The data obtained are rarely combined with data on child health. One exception is the German Environmental Survey for Children. In this survey, which is part of a larger study on child health in Germany (Kurth et al. 2008), a special module was undertaken from 2003 to 2006 to measure the influence of environmental factors on child health. Exposure to chemical pollutants, mould spores, and noise was examined using a representative sample of 1,790 children aged between 3 and 14 . In respect to indoor pollution, the survey shows that around $50 \%$ of the children were living in households with at least one smoker. However, the earlier years are not taken into account in this study. For a study that focuses on the earlier years in the German context, see Lüchinger (2009), who combines data from the Federal Environment Agency with data from birth statistics. However, given the data used in this study, it is not possible to control for a broader set

\footnotetext{
${ }^{1}$ There are other studies focusing on environmental issues in developing countries. For example, see the study by Kim (2009) who analyses the Impact of Rainfall on Early Child Health, also dealing with child mortality, in the first five years of a child's life.
} 
of child and family characteristics. This is something we can do in the present study using representative survey data.

We use data from the German Socio-Economic Panel (SOEP) combined with the data of the German Federal Environment Agency. Our work offers three important contributions. Firstly, we use accurate measures for five different pollutants on a (half-)hourly basis. Secondly, we are able to follow the effect of pollution exposure on a child's health during the first three years of life, accounting for time-invariant and unobserved neighborhood and mother-specific characteristics. Thirdly, we calculate different pollution intensity measures. Instead of relying solely on mean pollution levels, we are able to use (half-)hourly pollution levels as well as indoor pollution measurements for latent pollution exposure.

The rest of the paper is organized as follows: Section 2 introduces pivotal information about pollutants and measuring stations in Germany. Section 3 describes the data and descriptive statistics. Section 4 explains the method used. Section 5 presents the results, and Section 6 ends with a summary of the central results and an outlook.

\section{Background}

There are some U.S. studies focusing on air pollution and infant health. Not all of them focus on causal relationships. However, this is of particular importance since many studies that estimate a relationship between pollution and health have largely neglected to take into consideration that pollution exposure is endogenously determined when individuals make choices to maximize their wellbeing and thus move into cleaner environments. Parents with high preferences for cleaner air are more likely to move into areas with better air quality and are also more likely to invest more in their child's health. Failing to appropriately account for such actions can yield misleading estimates of the causal effect of pollution on health. This has to be taken into consideration when summarizing relevant studies.

One group of existing studies focuses on health immediately after birth. These studies observe infant mortality, low birth weight (LBW), preterm birth or gestational age (for a summary of these studies, see Currie et al. 2009). While epidemiological approaches regarding health and pollution widely exist, economic studies are rare. Some of these studies suffer from the fact that they do not take into account the endogeneity of pollution exposure. Two studies for California by Neidell (2004) and Currie and Neidell (2005) deal with the endogeneity by using 
within zip code variation in pollution levels. They focus on infant health, including birth weight, gestational age, infant mortality, and asthma. Neidell (2004) estimates the effect of air pollution on child hospitalizations for asthma using naturally occurring seasonal variations in pollution within zip codes. He found that the effect of pollution is greater for children of lower socio-economic status (SES), indicating that pollution is one potential mechanism by which SES affects health. However, both studies find no consistent pattern of pollution effects on health at birth.

The most recent study by Currie et al. (2009) for New Jersey has two improvements on the above-mentioned studies. Firstly, the closest measuring stations to the households are determined using the exact coordinates of the household address instead of the coordinates of the zip code center. Secondly, as well as accounting for unobservable heterogeneity of the neighborhood, the authors also controlled for unobserved characteristics of the mother. The results confirmed that $\mathrm{CO}$ has a significant effect on fetal health, birth weight and on infant mortality, even at low levels of pollution. The result is robust against different specifications.

For Germany, there is the above-mentioned study by Lüchinger (2009). The study estimates the effect of $\mathrm{SO}_{2}$ pollution on infant mortality in Germany from 1985 to 2003. To avoid simultaneity problems, the author exploits the natural experiment created by the mandated desulfurization at power plants, with wind directions dividing counties into treatment and control groups. He found that the observed reduction in pollution implies an annual gain of $850-$ 1,600 infant lives. Estimates are robust to controls for economic activity, climate, reunification effects, rural/urban trends and total suspended particulate pollution and are comparable across subsamples.

In our study, we control for unobservable time-invariant characteristics of the neighborhood and the mother in line with the study by Currie et al. (2009). But contrary to Currie et al. (2009), we employ five different air pollution values, carbon monoxide (CO), ozone $\left(\mathrm{O}_{3}\right)$, particulate matter $\left(\mathrm{PM}_{10}\right)$, nitrogen dioxide $\left(\mathrm{NO}_{2}\right)$, and sulfur dioxide $\left(\mathrm{SO}_{2}\right)$. For a short summary of the mechanisms how these pollutants could affect child health, see Appendix.

Given this rich set of different pollution measures, it is questionable which is the best value to use. In the literature, it is not very clear which pollution value is suitable for describing outliers as well as the duration of the exposure in an appropriate manner. For instance, the study 
by Currie et al. (2009) finds that the exposure in the last trimester of pregnancy influences birth outcomes significantly negatively at least for $\mathrm{CO}$, but not in the first and second trimesters. However, the result could point to the multicollinearity of the three mean values (see also algebraic signs in Section 4). Therefore, the problem is how to make use of the variety of measuring values ${ }^{2}$ in such a way that no important information is lost by aggregating the measuring values, and at the same time ensure that the variety of the (mean) values does not lead to multicollinearity in the results. For this reason, besides different mean value combinations, we also use latent factors that compress the variety of information to useful values.

\section{Data}

The main data used for this study is the German Socio-Economic Panel (SOEP). It is a representative national longitudinal data set for Germany that annually surveys households and all individuals 16 and over living in the household. The SOEP started in 1984 (Wagner et al. 2007). ${ }^{3}$ It provides an informative database with a rich set of indicators of both parents' and children's characteristics. Since 2003, detailed information on the health of children has been integrated into the SOEP by means of an additional questionnaire for mothers of very young children. For our analysis, we use data from the birth cohorts 2002 to 2007 . Given the specialties of the SOEP, we are able to distinguish between children in their first year of life (newborns) and children at two to three years of age. The sample size for the newborns varies between 1,154 to 1,268 and for the two- to three-year-olds we observe between 629 and 775 children. Given the information in the SOEP, we can use the following health measures: weight and height at birth, fetal growth, and any disorders a child may have (e.g. motor or visual impairments).

Each child can be linked with mother and family characteristics. We observe the mothers' age, education, and family formation. Moreover, we can match the fathers' information to child-related variables. We also match household-related variables to the children's characteristics. It includes household income and the municipality size and migration background. ${ }^{4}$ The data allow us to identify siblings born to the same mother.

\footnotetext{
${ }^{2}$ The yearly mean pollution value consists of $17,520=(2 \times 24 \times 365)$ single half-hourly pollution values.

${ }^{3}$ See http://www.diw.de/soep for more information on the SOEP.

${ }^{4}$ This is a dummy variable, which takes the value 1 if the mother or father or both parents have an immigration background and 0 otherwise.
} 
For both parents, we have information on their smoking behavior. This allows us to use this information as a measure for indoor pollution, which in turn allows us to approximate the air quality in the child's household.

For our analysis, we link the SOEP data with data from the Federal Environment Agency. We link the data in such a way that pollutants measures from the nearest measuring station of a SOEP household are matched. Since the exact coordinates of these measuring stations and the exact coordinates of the center of the zip-code area a SOEP household lives in are known, it was possible to identify the nearest station (short distance principle) for each year ${ }^{5}$ and each SOEP household. The distance between the station and the household is often less than a kilometer. In rural areas, the distance between the household and the measuring station is slightly greater. However, here the assumption applies that within rural areas, pollution levels do not change over great distances as much as in urban areas. The regional distribution of the SOEP households and the measuring stations is presented in Figure A1, Appendix. ${ }^{6}$

Detailed data on different air pollution levels cover the years 2002-2007. The data are measured at monitors. In Germany each state has between 11 (Bremen) and 268 (North RhineWestphalia) monitors. Altogether, 1,305 monitors of the states capture the air quality in Germany. The Federal Environment Agency gathers the determined measurements in a data base and provides information about the emission conditions in Germany, itemized with regard to the pollutants. Generally, it is unusual to measure all five pollutants used in our analysis at one measuring station. Frequently, $\mathrm{CO}, \mathrm{NO}_{2}$ und $\mathrm{PM}_{10}$ are measured together at one station, especially in traffic zones. ${ }^{7}$ Which stations measure which pollutants depends significantly on the location and its "problematic nature." For instance, sites with high traffic are equipped with measuring devices measuring the pollutants typical of this area only, such as $\mathrm{PM}_{10}, \mathrm{NO}_{2}$ and $\mathrm{CO}$. On the other hand, $\mathrm{O}_{3}$ is not a problem in areas close to traffic but it is in urban, suburban and rural areas. For $\mathrm{CO}, \mathrm{NO}_{2}, \mathrm{SO}_{2}$ and $\mathrm{O}_{3}$, half-hour values are measured for every station and every day, and hourly values for $\mathrm{PM}_{10}$. In our analysis, we use monthly means for the individual pollutants, which are calculated according to the guidelines for calculating and analyzing emission data on the basis of EoL (Exchange and Information) and the EU guide-

\footnotetext{
${ }^{5}$ This approach, which we had to use for data security reasons, is not as precise as using the exact household coordinates.

${ }^{6}$ Since not all the measuring stations in Germany measure all five air pollutants, there are households that have to be assigned to two measuring stations.

${ }^{7}$ Detailed information on which stations in Germany measure which pollutants can be found at http://www.envit.de/stationen/public/open.do (accessed August 10, 2010).
} 
lines. Mean values for a week, decade, month, and year are measured on the basis of (half-) hourly means. In EoL it is stipulated that hourly means may only be calculated when $75 \%$ of the data is available, i.e. both half-hourly means must be obtainable when calculating the hourly means. Based on the hourly means, daily means may only be calculated when at least 13 hourly means are available and when, at the same time, no more than six successive hourly means are missing.

The calculated average seasonal variation for the five pollutants for the years 2002-2007 can be seen in Fig. 1. The figure shows that for each air pollutant, considerable variation is observable not only within months but also over years.

Fig. 1: Seasonal variation in air pollution (2002-2007)
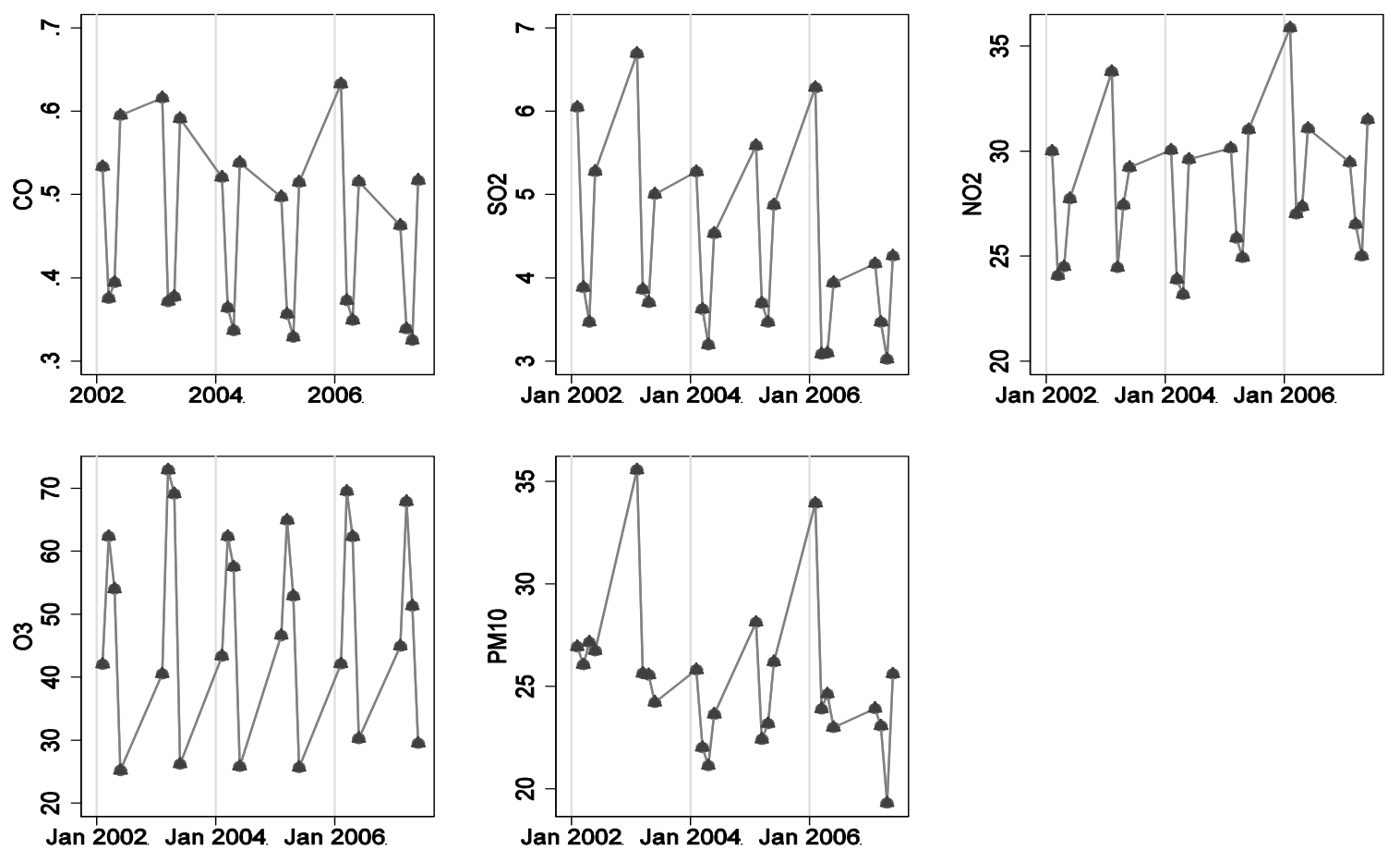

Source: Federal Environment Agency (2002-2007): own calculations.

In respect to child health, our data set offers various options. Finding the appropriate measure of a child's health status is a challenge (see also Case et al. 2002). Health has many dimensions, such as mental and physical health, chronic conditions, environmental conditions, nutrition and injuries. Studies on Western industrialized countries often use low birth weight (LBW) as an indicator of poor health at birth (for example, Oreopoulos et al. 2008). Alternative measures of children's health are bed days and hospitalization episodes. As there is still no operational global definition of child health, it might be useful to use various measures 
once they become available. This is a crucial advantage of the data used here. The SOEP allows us to observe different types of health measures for the children (for other SOEP-based studies using similar child health measures, see, for instance, Dunkelberg and Spiess 2009, Cawley and Spiess 2008, and Coneus and Spiess 2008). For all age cohorts, we observe anthropometric (health) measures such as weight and height of the child. Anthropometric health measures have the advantages that they are easy to administer and that potential measurement errors are more likely to be random. Weight and height of the children are reported by the mother. Thus, there might be reporting errors (see, for instance, Strauss and Thomas 1996), but we argue that the reporting error is low and random, given the specific features of the German health care system.

Fig. 2: Seasonal variation in child health outcomes, first year of life (2002-2007)
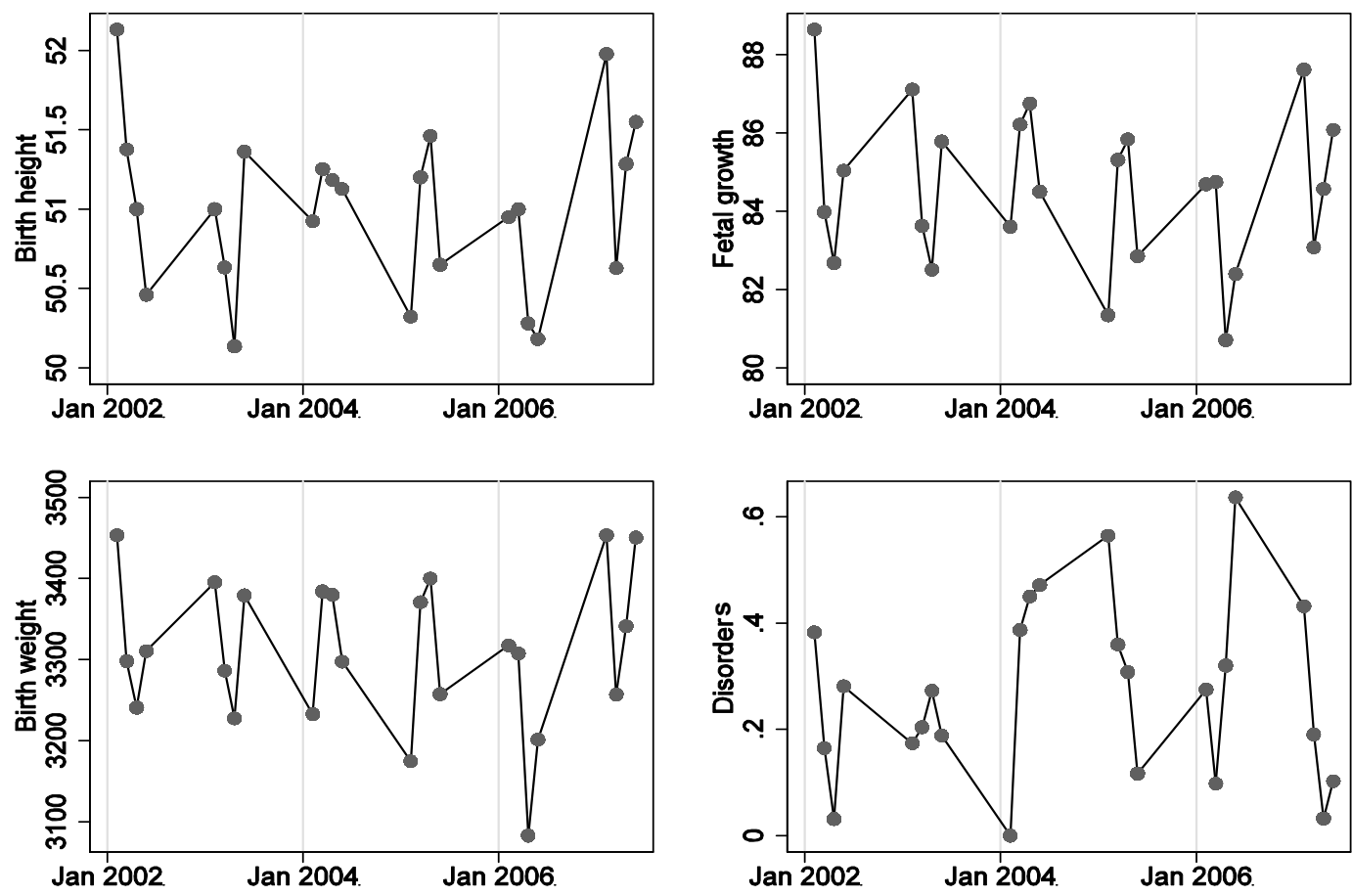

Source: SOEP 2002-2007: own calculations.

In Germany, preventive medical check-ups are offered to children on a regular basis from birth up to the age of five. They are free of charge. The weight and height of the child are taken by experts at each check-up and documented in a medical record booklet that is kept by the family. $98 \%$ of SOEP children have had such regular check-ups. In our data, the average weight (height) at birth is 3,327.23 grams $(51.15 \mathrm{~cm})$ (see Table A2, Appendix). For our analysis, we calculate fetal growth, which is the birth weight divided by gestational age. The mothers are also asked about any disorder their child may have (covering chronic illnesses, 
neurological disorders, physical disabilities, and other impairments). $6 \%$ of the mothers in our sample report such a disorder. In Fig. 2, we present the distribution of the child health variables at birth over time. It can be shown that there is variation between months as well as over time.

Two years later, mothers were asked again about any disorders their child had, for example, motor impairments or asthma. We compute a dummy variable for having bronchitis, croup syndrome, respiratory disease or any other disorder. Again, we would expect that given the regular medical check-ups in Germany during the first five years of a child's life, measurement errors are low and random. This time $46 \%$ of the mothers reported a disorder. See Fig. 3 for a distribution of child health at two to three years of age. All health measures show seasonal as well as yearly variation.

Fig. 3: Seasonal variation in child health outcomes at two to three years of age (20052007)
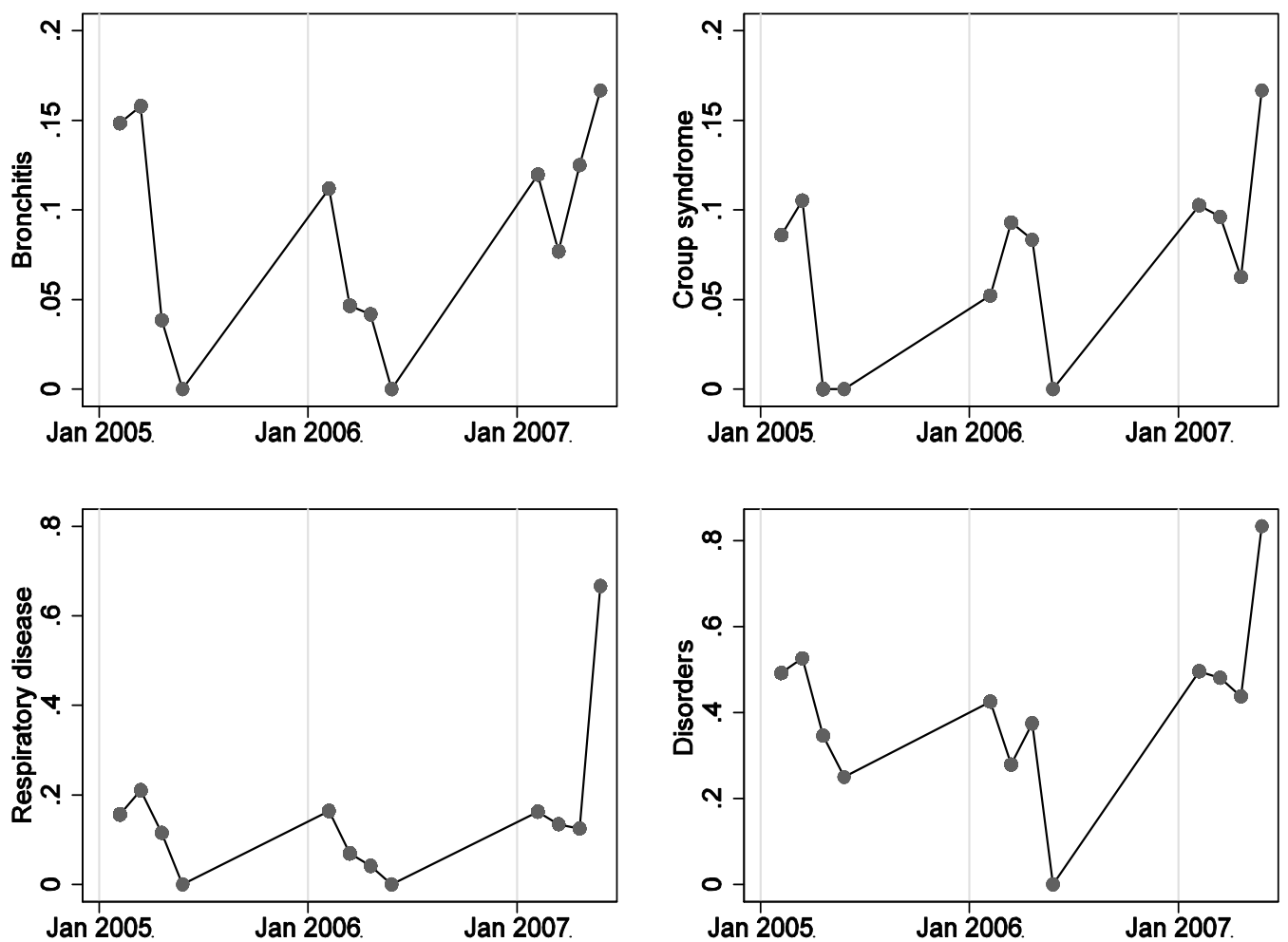

Source: SOEP 2002-2007: own calculations.

Table A2 presents summary statistics for infant health, pollution measures and control variables at birth, for the first year of life and at the age of two to three years. The mean values for the various air pollutants seem to lie very closely together. This applies to children in their first year of life as well as to the two- to three-year-olds. For air pollution caused by smoking in households measured with the number of cigarettes, there are barely any differences be- 
tween the very young children and the two- to three-year-olds. However, the number of mothers and fathers who smoke seems to be slightly higher among the two- to three-year-olds. Significant variations in the control variables between both samples only occur for the share of single parents. The share for newborns is still at 7\%; it has more than doubled two to three years later.

\section{Conceptual Framework}

For both age groups, we estimate the effect of ambient pollutants and indoor pollution on a child's health. While ambient pollution is relatively randomly assigned, it has, however, to be taken into account that the extent of pollution exposure is not endogenous. The decision to live in a cleaner area depends on family-related background variables, such as education, immigration background and income because living in a better neighborhood often implies higher housing prices. It is to be expected that parents who choose a better neighborhood are also more likely to invest more in the health of their children. As a result, pollution exposure might be higher where individuals are poorer and poorer individuals are more likely to invest less in infant health. Additionally, an individual's pollution exposure might also be correlated with avoidance behavior. Individuals can react to pollution alerts by decreasing the duration and the time of day spent outside or by reducing stressful activities such as jogging or other types of sport. If these variables are potentially correlated with a child's pollution exposure, omitting them leads to biased estimates. Whether the bias is an up-or downward bias is driven by two confounding effects. On the one hand, families with high preferences for cleaner air are more likely to invest in health, which leads to an overestimate of the true impact. On the other hand, pollution levels in urban areas are higher. Frequently, more educated individuals live there and the infrastructure is normally better, which might lead to an underestimate of the true impact of pollution on health. However, the variation in pollution exposure in urban areas is quite large so if highly educated parents decide to live in urban areas, it is likely that they will choose districts with a high quality of living. This might moderate the underestimation of the true impact.

Model for children in their first year of life. We estimate the impact of pollution exposure on a child's health at birth using the following health measures for newborns: height and weight at birth, fetal growth, and a dummy for a disorder in the first year of life. 
Estimation equation for outdoor pollution:

$$
\text { health }{ }_{z y t i j}=\beta_{0} P_{z y t i j}+\beta_{1} X_{z y t i j}+Y_{t}+u_{z y t i j}
$$

In equation (1a), health denotes our health outcomes in zip code $z$, in year $y$ in the quarter of year $t$ of the individual $i$ in family $j$. The vector $X$ includes observable characteristics of the child, the mother, the father and the household (for a detailed description see below). The coefficient $\Omega$ is our main parameter of interest and measures the impact of air pollution $P$ in zip code $z$, in year $y$ in the quarter of year $t$ of the individual $i$ in family $j$ on a child's health $i$. We calculate four different pollution values $P$ to estimate the impact of pollution exposure on a child's health at birth:
a) mean pollution exposure for each pollutant at birth
b) mean pollution exposure for each pollutant during pregnancy
c) latent pollution exposure factor by trimester during pregnancy
d) latent maximum pollution exposure factor by trimester during pregnancy

Altogether, we use four different outdoor pollution measures a -d, to estimate the impact of outdoor pollution exposure on infant health.

\section{Estimation equation for outdoor and indoor pollution:}

$$
\text { health }_{z y t i j}=\beta_{0} P_{z y t i j}+\beta_{1} X_{z y t i j}+\beta_{2} I_{z y i j}+Y_{t}+u_{z y t i j}
$$

In equation $(1 \mathrm{~b})$, we include one latent factor for outdoor pollution $P$ during pregnancy and one latent factor for indoor pollution $I$, using smoking cigarettes as a proxy for indoor pollution exposure, because this gives a better approximation of the overall air quality.

\section{Estimation equation for indoor pollution:}

$$
\text { health } h_{y t i j}=\beta_{1} X_{y t i j}+\beta_{2} I_{y i j}+u_{y t i j}
$$

Finally, we estimate the impact of indoor pollution $I$ on a child's health using four different measures for indoor pollution $I$ :

a) a dummy whether the mother smokes

b) a dummy whether the father smokes 
c) a dummy for both

d) the total number of cigarettes smoked in the household during the sample period

Thus, we use four measures for indoor pollution to estimate the impact of indoor pollution on infant health.

In the estimation equations (1a) and (1b), the different pollution levels are calculated using the nearest monitor to the household residence in zip code $z$. Then $/$ measures the effect of a change in mean pollution levels within $t$ while $x_{z y t i}$ captures observable characteristics of the child, mother, father, and household which might be correlated with both pollution exposure and health. They include gender of the child, birth order, and mother-specific characteristics such as education, age, immigration background and single parenthood, as well as householdrelated variables such as income and municipality. Finally, $Y_{t}$ includes controls for seasonal changes because these are highly correlated with pollution levels. It includes all months and year dummies for our whole sample period.

As mentioned above, this estimation strategy suffers as a result of the fact that unobserved time-invariant characteristics of the area are not taken into account but are potentially correlated with pollution and health. Ignoring this issue will not capture the "biological" effect of pollution exposure on child health. To overcome this problem, we estimate the following model:

(2a) health $h_{z y t i j}=\beta_{0} P_{z y t i j}+\beta_{1} X_{z y t i j}+Y_{t}+\alpha_{z y}+u_{z y t i j}$

(2b) health ${ }_{z y t i j}=\beta_{0} P_{z y t i j}+\beta_{1} X_{z y t i j}+\beta_{2} I_{z y i j}+Y_{t}+\alpha_{z y}+u_{z y t i j}$

In estimation equations (2a) and (2b), we include $\in_{z y}$, which is a fixed effect for each year at zip-code level. ${ }^{8}$ Accounting for fixed effects at zip-code level will capture a large share of potentially unobserved omitted and time-invariant average characteristics of the neighborhood within one season. In this model, we estimate birth outcomes of children living in close proximity to each other and who are born in the same month $t$. Given the fact that parents who are also more likely to invest more inputs in the health of the children might adjust their behavior towards pollution alerts by choosing to spend time indoors or do alternative outdoor activities,

\footnotetext{
${ }^{8}$ For indoor pollution, we do not have to account for neighborhood effects.
} 
the model presented in equation $(2 \mathrm{a}, \mathrm{b})$ might be still biased. To remove the influences of potentially confounding factors resulting from unobserved characteristics (behavior) from the mother, we include a mother fixed effect in model (3a) - (3c).

(3a) health $h_{z y t i j}=\beta_{0} P_{z y t i j}+\beta_{1} X_{z y t i j}+Y_{t}+\alpha_{z y}+\lambda_{j}+u_{z y t i j}$

(3b) health ${ }_{z y t i j}=\beta_{0} P_{z y t i j}+\beta_{1} X_{z y t i j}+\beta_{2} I_{z y j}+Y_{t}+\alpha_{z y}+\lambda_{j}+u_{z y t i j}$

(3c) health $h_{y t j}=\beta_{1} X_{y t i j}+\beta_{2} I_{y i j}+\lambda_{j}+u_{y t i j}$

Models (3a)-(3b) control for unobserved time-invariant characteristics of both the neighborhood and the mother. The indoor pollution model includes a mother fixed effect (3c). The effect of air pollution on a child's health at birth is now identified by variation in pollution between siblings in a particular area. A prerequisite for identifying this is that the unobservable fixed effects of the mother do not differ systematically with regard to the children. This assumption may be violated if, for instance, the parents systematically alter the relation of time one child spends indoors and outdoors due to a smog alert but do not reduce the time spent outdoors by another child.

Models for the two- to three-year-olds. We also estimate all models presented above for the two- to three-year-olds. As health outcomes, we observe whether the child has bronchitis, croup syndrome, respiratory disease or other disorders. The age of the children varies between 26-47 months so we control for age in months in all models. In order to better approximate the consequences of air pollution on the child's health during the first few years of life, we calculate pollution intensities during the entire period from birth (pregnancy) up to age two to three. Overall, $\neg$ measures five different pollution intensities:

a) mean pollution exposure for each pollutant during the last year

b) latent pollution exposure factor during the last year

c) latent pollution exposure factor during the last month

d) mean (monthly) pollution exposure for each pollutant during the interview month

e) three-year mean for each pollutant

For both age groups and each pollutant, three different models are estimated. The first model is an ordinary least squares model, the second model includes a fixed effect for the zip-code 
area and in the third model we include an area and family fixed effects. The later is restricted to mothers with at least two children. The standard errors are clustered on the household level. ${ }^{9}$

\section{Results}

Results for children in their first year of life. Table A3 presents the estimation results for the first age group and for all five air pollutants. All three models include the variables described in Table A2, but only the various effects of the five air pollution measures on the birth height, birth weight, fetal growth, and disorders are shown. As indicated in Tables A3 and A4, CO exposure during pregnancy and at birth has a significantly negative impact on fetal growth and the birth weight in model 3 (equation 3a). Hence, it becomes apparent that CO impairs the ability of the blood to transport oxygen and, therefore, supply it to the fetus. A high exposure to $\mathrm{CO}$ at birth causes, on average, a 289 gram lower weight at birth. Here, the impact on birth weight and fetal growth towards the end of pregnancy appears to be significantly higher than at the beginning and the middle of pregnancy. Taking into consideration the mean value of $\mathrm{CO}$ exposure during pregnancy, the latent exposure during a trimester and the maximum exposure during a trimester, the total impact is at least 100 grams less. This outcome is thus in line with the results found by Currie et al. (2009), with often only the last trimester of pregnancy being at all significant. For $\mathrm{O}_{3}$, the effect of exposure appears to be negative throughout the entire pregnancy, not only at the end. This holds for birth height, birth weight and fetal growth. For a higher exposure with $\mathrm{NO}_{2}$ and $\mathrm{SO}_{2}$, we find a negative impact on birth height and the probability that there are disruptions at birth. Overall, the negative impact of $\mathrm{SO}_{2}$ is greater than that of $\mathrm{NO}_{2}$. For $\mathrm{PM}_{10}$, we find no impact in most models and specifications that account for unobservable neighborhood effects as well as for unobservable effects within the family. Twice, we find a positive effect for the mean effect of fine particles at birth for fetal growth and birth weight. We also observe this implausible effect in Currie et al. (2009). A possible explanation could be that fine particles tend to cause long-term impairments of the airways (cancer, pneumoconiosis), which is certainly harmful for fetuses but cannot easily be revealed due to the variation of our model, which is designed to cover the short term.

Table A4 shows how the overall air pollution in and outside of the house has an impact on the child's health at birth. In most models, a pattern for ambient air pollution from Table A3 emerges where no impact of indoor pollution is observable - with the exception of the nega-

\footnotetext{
${ }^{9}$ For all models with latent factors, the standard errors were bootstrapped with 500 replications.
} 
tive effects for the $\mathrm{PM}_{10}$ models - when the unobservable neighborhood effects and family effects are controlled for. This effect may result from the smaller variation within the family with regard to the parents' smoking behavior. For further insights, we estimate models covering the indoor pollution only. The OLS results of air pollution due to smoking are depicted in Table A5. ${ }^{10}$ A dummy whether the mother smokes is included in column 1 next to all control variables, column 2 shows whether the father smokes, column 3 contains two dummies whether the mother and father both smoke, and column 4 contains a variable that reflects the total number of cigarettes smoked in a household. Almost all models show that the mother's smoking has a negative impact on the birth outcomes, whereas the father's smoking and the associated mother's passive smoking during pregnancy do not seem to be harmful. However, the smoking intensity and, consequently, the air quality in the house also impair fetal growth and reduce the birth weight. For each cigarette smoked in the household during pregnancy, weight decreases on average 3.84 grams.

In respect to disorders, the results show that the higher the $\mathrm{O}_{3}$ level in a neighborhood during pregnancy, the more children have some kind of disorder in their first year of life. A similar effect applies for the $\mathrm{SO}_{2}$ level. There is no effect on indoor pollution and a disorder of the child in the first year of life (see Table A5).

Results for two- to three-year-olds. The effects of the five air pollutants on selected health indicators is depicted in Table A6. Analogous to the newborns, in model (1) we present OLS results, in model (2) we control for area FE, and in model (3) we also take into account family FE. Contrary to the results of the younger children, it has to be considered that our sample consists of around 300 observations less and that the temporal variation (2005-2007) and variation within the family is significantly smaller. For this reason, identifying air pollution effects is particularly difficult in models 2 and 3 and, therefore, we strongly argue for the accuracy of the results of the first models (OLS models). In most specifications, $\mathrm{O}_{3}$ exposure leads to an increased probability of falling ill with bronchitis, respiratory diseases and having any impairment at all. This view is approved for some specifications and is partly even robust when an area FE and a family $\mathrm{FE}$ are taken into account. $\mathrm{PM}_{10}$ also increases the probability of

\footnotetext{
${ }^{10}$ As smoking is only considered every two years in the SOEP, it is not possible to find out for all children whether their mother smoked during pregnancy. Therefore, the family fixed effect models are only identifiable for a small sample.
} 
falling ill with bronchitis and respiratory diseases. These effects even occur in our models that account for area and family FE. No clear pattern emerges for $\mathrm{CO}, \mathrm{SO}_{2}$ or $\mathrm{NO}_{2}$.

Table A7 shows the impact of the overall air pollution on child's health at the ages of two to three years. Consistent with the results from Table A6, a higher $\mathrm{O}_{3}$ exposure leads to an increased likelihood of respiratory diseases, bronchitis or other impairments. In some models, indoor pollution also increases the probability of suffer from one of the above conditions; however, there does not appear to be an accumulated outdoor and indoor pollution effect. Table A8 shows the impacts of indoor pollution (same measurements for the newborns) on the health of the two- to three-year-olds. The results in Table A8 suggest that indoor pollution does not seem to have a significant impact of the health measures at this age.

\section{Conclusion}

Nowadays it is a generally accepted fact that air pollution should be regulated for many reasons, including the health of human beings. The health of children in their early years is of particular interest in this respect since in the short term children's health is very vulnerable and in the long term early childhood health is important for the development and skill formation of children. Consequently, in the last few years, several economists mainly in the U.S. context have begun to analyze the impact of air pollution on child health (see Section 2). This poses various challenges, starting with finding the appropriate health measures and measures for air pollution for obtaining an accurate estimate of the causal impact of air pollution. Two major obstacles here are the presence of confounding factors brought about through residential sorting and the lack of health measures that capture the range of morbidities purportedly related to pollution.

Given the above, our analysis is one attempt to use representative German data to cope with these problems. We analyze the effect of air pollution on children's health using area as well as panel models in which we account for both area and family fixed effects. We use different health measures such as anthropometric measures and the occurrence of particular impairments which are known to have some correlation with air pollution, such as bronchitis. The pollution measures we use cover a wide range of measures. This is another advantage of this study. We use accurate measures for five different pollutants $\left(\mathrm{CO}, \mathrm{NO}_{2}, \mathrm{SO}_{2}, \mathrm{O}_{3}\right.$, and $\left.\mathrm{PM}_{10}\right)$ on a (half-)hourly basis. On the basis of this data, we calculate different pollution intensity measures. Instead of relying solely on mean pollution levels, we are able to use (half-)hourly 
pollution levels for the total latent pollution exposure. We do not use outdoor measures only; we take information on parental smoking behavior as a proxy for indoor pollution.

Our analysis covers two age groups, newborns and children aged two to three. Thus, our analysis gives some indication oft which age groups the effects are more pronounced in. Moreover, our studies allow us to analyze the effect of different pollutants. Therefore, it gives further evidence which pollutants matter most for child health and which ones are of minor importance. Apart from the study by Lüchinger (2009), this study is the only one focusing on a potential causal relationship between pollution and child health for an industrialized country other than the U.S. In general, air pollution in Germany is less of a problem than in the U.S., although in urban areas in particular it is still a major concern.

Our estimation results show that air pollution matters, particularly directly after birth. CO levels affect fetal growth and birth weight. As traffic is the main reason for $\mathrm{CO}$ pollution in the air, policies and attempts to make cars more friendly for the environment seem to be important from the perspective of child health as well. This is especially true since infants and young children in particular are threatened by a high $\mathrm{CO}$ level, as even the smallest concentration might lead to damage of the fetus's brain cells. Moreover, the risks are especially high for children whose mothers smoke. This is of further relevance because our studies show that overall $20 \%$ of the mothers in our sample of infants smoke and that this smoking behavior is affecting birth weight and fetal growth. This effect is stronger if both parents smoke. If this is the case, the birth weight of children is 176 grams lower, compared to 145 gram if we only control for mother's smoking behavior.

Furthermore, our estimations show evidence of an effect of $\mathrm{O}_{3}$ levels on children's probability of having a disorder of some type. $\mathrm{O}_{3}$ is considered to be the routing substance of summer smog. Therefore, infants and toddlers are affected by increased $\mathrm{O}_{3}$ levels much more than adults because their breathing frequency is higher and they have a higher demand for oxygen. Furthermore, the defense system of the infantile immune system is not yet fully developed. Consequently, there is a particular cause for concern in areas with a high risk of summer smog. Similar results can be measured for the $\mathrm{SO}_{2}$ level. Oxidation processes of $\mathrm{SO}_{2}$ lead to sour rain. Again areas with a high risk of sour rain pose a cause for concern since this has effects on child health. With our older group of children, the two- to three-year-olds, we 
mainly find effects for the $\mathrm{O}_{3}$ level. This increases the probability of having bronchitis or respiratory disease. Thus, summer smog might be one cause of these types of impairments.

From a policy perspective, our results on the one hand underline all approaches, such as public campaigns or consultations with pediatricians and other experts to ensure that parents of infants are aware of the negative consequences of their smoking behavior on the health and development of their child. On the other hand, our results underline the efforts made on the regional and national level to lower $\mathrm{CO}$ and $\mathrm{O}_{3}$ levels in particular. As they are higher in urban areas, environmental policies should focus on reducing these pollutants in these areas in order to improve child health.

Nevertheless, our study could benefit from further research using even more precise pollution measures, for example, personal air quality monitors strapped to persons. As long as these data are not available for representative larger data sets, all the information obtained may be interpreted as very conservative estimations since they might well underestimate the actual effects (see Currie et al. 2009). 


\section{Literature}

Case, A., Lubotsky, D. and Paxson, C. (2002). Economic Status and Health in Childhood: The Origins of the Gradient, American Economic Review 92 (5): 1308- 1334.

Cawley, J. and C. K. Spiess (2008). Obesity and Skill Attainment in Early Childhood, in: Economics and Human Biology 6 (3): 388-397.

Coneus, K. and C. K. Spiess (2008). The Intergenerational Transmission of Health in Early Childhood, ZEW Discussion Paper No. 08-073.

Currie, J. and M. Neidell (2005). Air Pollution and Infant Health: What Can We Learn from California's Recent Experience? Quarterly Journal of Economics, 120(3), 1003-1030.

Currie, J., M. Neidell and J. Schmieder (2009). Air Pollution and Infant Health: Lessons from New Jersey. Journal of Health Economics, 28(3), 688-703.

Currie, J. (2009). Healthy, Wealthy, and Wise: Socioeconomic Status, Poor Health in Childhood, and Human Capital Development. Journal of Economic Literature, 47 (1), 87122.

Dunkelberg, A. and C. K. Spiess. (2009). The Impact of Child and Maternal Health Indicators on Female Labor Force Participation after Childbirth - Evidence for Germany, in: Journal of Comparative Family Studies 40: 119-138.

Kim, Yeon Soo (2009): The Impact of Rainfall on Early Child Health, November, 2009. mimeo.

Kurth, B.-M. et al. (2008). The challenge of comprehensively mapping children's health in a nation-wide health survey: Design of the German KiGGS-Study. In: BMC Public Health 8, 196.

Lüchinger, S. (2009). Air Pollution and Infant Mortality: A Natural Experiment from Power Plant Desulfurization, Working Paper.

Neidell, M. (2004). Air Pollution, Health and Socio-Economic Status: The Effect of Outdoor Air Quality on Childhood Asthma. Journal of Health Economic, 23(6), 1209-1236.

Oreopoulus, P, M. Stabile, R. Walld and L. Roos (2008). Short, Medium, and Long Term Consequences of Poor Infant Health: An Analysis using Siblings and Twins. Journal of Human Resources, 43(1), 88-138.

Strauss, J. and D. Thomas (1996). Measurement and Mismeasurement of Social Indicators, American Economic Review 86 (2): 30-34.

Wagner, G. G., J. R. Frick and J. Schupp (2007). The German Socio-Economic Panel Study (SOEP) - Scope, evolution, and enhancements. Schmollers Jahrbuch, 127, 139-169. 


\section{Appendix}

\section{Mechanisms through which pollutants might affect child health}

CO is a colorless, odorless and flavorless gas. It is contained in the fumes of motor vehicles and emerges when heating water, heating by coal and smoking cigarettes. The main reason for $\mathrm{CO}$ pollution in the air is traffic. CO impairs the intake of oxygen and leads, even in small quantities, impacting the central nervous system. $\mathrm{CO}$ is transferred from the lungs to the blood and attaches itself to the hemoglobin of the erythrocytes or red blood cells. The attachment of CO to these cells is 200 times stronger than that of oxygen. Consequently, CO paralyzes the erythrocytes and does not allow them to take in oxygen, which is crucial for the functioning of the organs, particularly the heart, brain and muscles. The performance of the heart decreases while the risk for blood vessels increases. This impairs the oxygen supply during pregnancy. Infants and children are threatened in particular, as even the smallest concentration might lead to damage of the fetus's brain cells. ${ }^{1}$ The risks are especially high for children whose mothers smoke. Since January 1, 2005, the limit of CO must not exceed the 8-hour average value of a day, which is $10 \mathrm{mg} / \mathrm{m}^{3}$.

The colorless and poisonous gas $\mathbf{O}_{3}$ is one of the most important trace gases in the atmosphere. It is generated from precursor pollutants (nitrogen oxides and volatile organic compounds) with intensive isolation via photochemical processes. $\mathrm{O}_{3}$ is considered to be the routing substance of summer smog. Increased $\mathrm{O}_{3}$ concentration can lead to impairments of the lung function or lung diseases in humans because it penetrates the respiratory tract. Ten percent of humans are oversensitive to $\mathrm{O}_{3}$, among them especially children, allergy sufferers and asthmatics. High $\mathrm{O}_{3}$ levels damage the mucous membranes of the airway in particular. Therefore, children and toddlers are affected by raised $\mathrm{O}_{3}$ levels to a much greater extent because their breathing frequency is higher and they have a higher demand for oxygen than adults. Furthermore, the defense system of the infantile immune system is not yet fully developed. For $\mathrm{O}_{3}$ concentration, there is an information threshold of $180 \mu \mathrm{g} / \mathrm{m}^{3}$ and an alarm threshold of $240 \mu \mathrm{g} / \mathrm{m}^{3}$. For the protection of human health, a maximum eight-hour value of $120 \mu \mathrm{g} / \mathrm{m}^{3}$ has been determined as a target value for 2010 . It may only exceed this value on 25 days a calendar year at the most.

\footnotetext{
${ }^{1}$ http://www.jameda.de/blog/hebammen/kohlenmonoxid-laesst-saeuglinge-und-kinder-bereits-bei-geringsterkonzentration-empfindlicher-fuer-krankheiten-werden/ (accessed 9/12/2010)
} 
The main reasons for the formation of $\mathbf{N O}_{2}$, as with $\mathrm{CO}$ and $\mathrm{PM}_{10}$, are processes of combustions in industry and power generation plants and traffic. In combination with hydrocarbon, nitrogen oxides are responsible for the aestival formation of $\mathrm{O}_{3}$. In the winter half of the year, ammonium nitrate particles emerge and contribute to the fine particle pollution. In the outside air, $\mathrm{NO}_{2}$ always occurs in combination with other substances. The effect is probably not solely caused by $\mathrm{NO}_{2}$ but by the concurrence with other substances, in combination with which $\mathrm{NO}_{2}$ always occurs, especially with fine particles from traffic. It harms the mucous membranes of the airway and impairs the respiratory function. The onehour threshold value for $\mathrm{NO}_{2}$ has been set to $200 \mu \mathrm{g} / \mathrm{m}^{3}$ (by 2010, plus an annually decreasing tolerance margin), which must not exceed the value more than 18 times during a calendar year. The threshold value for a year amounts to $40 \mu \mathrm{g} / \mathrm{m}^{3}$ (by 2010 , also with an annually decreasing tolerance margin). ${ }^{2}$

$\mathbf{S O}_{2}$ is a colorless gas with a pungent smell, water-soluble and highly toxic. It emerges especially when burning fossil energy carriers - coal and oil. Oxidation processes lead to sour rain. Sulfate particles, emerging in the atmosphere from $\mathrm{SO}_{2}$, contribute to the pollution with fine particles $\left(\mathrm{PM}_{10}\right)$. Even a small concentration of $0.04 \%$ may lead to severe poison phenomena such as corneal haze, breathlessness, and inflammations of the respiratory tract higher concentrations may be fatal. In humans, $\mathrm{SO}_{2}$ causes impairment of the respiratory tract, especially in combination with dust: It irritates the mucous membranes, which may lead to tissue mutation of the upper respiratory tract and higher infection sensitivity. The one-hour threshold value was set to $350 \mu \mathrm{g} / \mathrm{m}^{3}$ on January $1^{\text {, t }} 2005$ and must not exceed this value more than 24 times a year. The daily threshold value of $125 \mu \mathrm{g} / \mathrm{m}^{3}$ may not be exceeded more than three times a calendar year. ${ }^{3}$

$\mathbf{P M}_{10}$ describes the mass of all particles included in the total of dust, the aerodynamic diameter of which is smaller than $10 \mu \mathrm{m}$. It may be of natural origin (for example, as a result of soil erosion) or be evoked by human action. It emerges from energy supply or industry plants and also in metal and steel processing. In conurbation, traffic is the dominant reason for fine particles. Airflow transports these fine particles over long distances. Fine particles are, in contrast to all other pollutants, from the smallest unit on, always harmful for health while for other pollutants, certain threshold values have to be passed in order to induce an impact dangerous to health. When there is a high concentration of fine particles, respiratory illnesses

\footnotetext{
${ }^{2}$ To assess the mass concentration of $\mathrm{NO}_{2}$ and nitrogen oxide, the chemiluminescence procedure is applied.

${ }^{3}$ To assess the concentration of $\mathrm{SO}_{2}$, the UV fluorescence procedure is applied.
} 
or cardiovascular diseases can increasingly occur, as well as impairments of the immune system. Individuals with pre-existing diseases are especially prone. Studies have shown a measurable decrease in life expectancy. The health risk is dependent in particular on how deep the particles enter the respiratory tract and how long they remain there. Smaller particles are even more harmful as they can enter the bloodstream. Heavy metals or carcinogenic hydrocarbons (PAK) may lay on the surface. Increased strains during pregnancy may lead to alteration of the breathing frequency of the newborns and lead to respiratory inflammations. New threshold values for fine particles $\left(\mathrm{PM}_{10}\right)$ have been introduced on 01.01.2005. The daily threshold value amounts to $50 \mu \mathrm{g} / \mathrm{m}^{3}$ and must not exceed this value more than 35 times a year. As there is less or no air exchange in the wintertime, a transgression of the threshold value occurs more frequently then. 
Fig. A1: Distance of SOEP households with children to "background" monitors

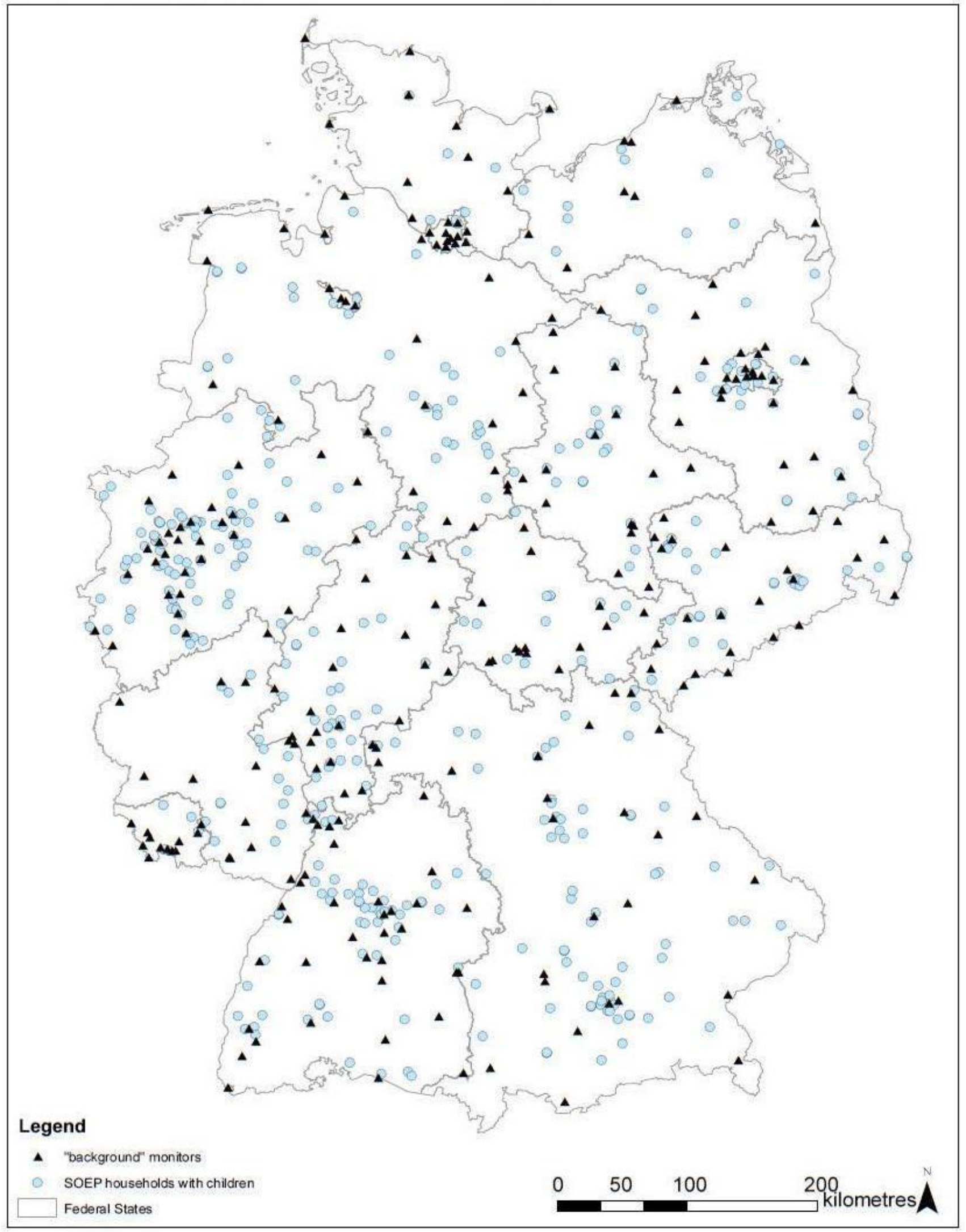

Note: Location of air monitors in Germany: own calculations. 
Table A1: Threshold for pollution levels

\begin{tabular}{|l|l|l|}
\hline \hline Pollutant & Limits per day & $\begin{array}{l}\text { Max. no. of days per year limit may } \\
\text { be exceeded }\end{array}$ \\
\hline $\mathrm{CO}$ (carbon monoxide) & $10 \mu \mathrm{g} / \mathrm{m}^{3}$ (eight-hour average) & - \\
\hline $\mathrm{O}_{3}$ (ozone) & $\begin{array}{l}120 \mu \mathrm{g} / \mathrm{m}^{3} \quad \text { (eight-hour } \\
\text { average) }\end{array}$ & 25 \\
\hline $\mathrm{PM}_{10}$ (particulate matter) & $50 \mu \mathrm{g} / \mathrm{m}^{3}$ & 35 \\
\hline $\mathrm{NO}_{2}$ (nitrogen dioxide) & $200 \mu \mathrm{g} / \mathrm{m}^{3}$ (one-hour average) & 18 \\
\hline $\mathrm{SO}_{2}$ (sulfur dioxide) & $125 \mu \mathrm{g} / \mathrm{m}^{3}$ & 3 \\
\hline \hline
\end{tabular}

Note: The boundary values were again increased in 2005.

Source: Federal Environment Agency in Germany.

\section{Table A2: Summary statistics}

\begin{tabular}{|c|c|c|c|c|c|}
\hline & \multicolumn{2}{|c|}{$\begin{array}{c}\text { Infants up to the age } \\
\text { of one }\end{array}$} & & \multicolumn{2}{|c|}{$\begin{array}{l}\text { Two- to three- } \\
\text { year-olds }\end{array}$} \\
\hline & mean & std.dev. & & mean & std.dev. \\
\hline \multicolumn{6}{|l|}{ Child health outcomes } \\
\hline Birth height (in cm) & 51.15 & $(3.06)$ & Bronchitis (yes $=1$ ) & 0.10 & $(0.29)$ \\
\hline Fetal growth (grams/week) & 84.98 & $(12.98)$ & Croup syndrome $($ yes $=1)$ & 0.08 & $(0.28)$ \\
\hline Birth weight (in grams) & 3327.23 & $(579.97)$ & Respiratory disease $($ yes $=1)$ & 0.14 & $(0.35)$ \\
\hline Disorder $($ yes $=1)$ & 0.06 & $(0.24)$ & Disorder $($ yes $=1)$ & 0.46 & $(0.50)$ \\
\hline \multicolumn{6}{|l|}{ Pollutants (outdoor) } \\
\hline $\mathrm{CO}$ (24 $\mathrm{h}$ average during birth month) & 0.46 & $(0.25)$ & $\mathrm{CO}(24 \mathrm{~h}$ average during interview month) & 0.48 & $(0.21)$ \\
\hline $\mathrm{O}_{3}$ (24 h average during birth month) & 45.97 & $(20.17)$ & $\mathrm{O}_{3}$ (24 $\mathrm{h}$ average during interview month) & 52.81 & $(16.24)$ \\
\hline $\mathrm{NO}_{2}$ (24 $\mathrm{h}$ average during birth month) & 31.72 & $(16.69)$ & $\mathrm{NO}_{2}$ (24 $\mathrm{h}$ average during interview month) & 30.43 & $(17.98)$ \\
\hline $\mathrm{SO}_{2}(24 \mathrm{~h}$ average during birth month) & 4.70 & $(2.85)$ & $\mathrm{SO}_{2}$ (24 $\mathrm{h}$ average during interview month) & 4.61 & $(2.31)$ \\
\hline $\mathrm{PM}_{10}$ (24 $\mathrm{h}$ average during birth month) & 26.84 & $(9.25)$ & $\mathrm{PM}_{10}$ (24 $\mathrm{h}$ average during interview month) & 27.77 & $(7.80)$ \\
\hline $\mathrm{CO}$ (24 $\mathrm{h}$ average last year before birth) & 0.46 & $(0.22)$ & $\mathrm{CO}$ (24 $\mathrm{h}$ average last year before interview) & 0.46 & $(0.18)$ \\
\hline $\mathrm{O}_{3}$ (24 $\mathrm{h}$ average last year before birth) & 46.17 & $(12.62)$ & $\mathrm{O}_{3}$ (24 $\mathrm{h}$ average last year before interview) & 48.47 & $(13.08)$ \\
\hline $\mathrm{NO}_{2}$ (24 h average last year before birth) & 32.06 & $(15.23)$ & $\mathrm{NO}_{2}(24 \mathrm{~h}$ average last year before interview) & 29.19 & $(16.80)$ \\
\hline $\mathrm{SO}_{2}(24 \mathrm{~h}$ average last year before birth) & 4.82 & $(2.41)$ & $\mathrm{h}$ average last year before interview) & 4.27 & $(1.86)$ \\
\hline \multirow[t]{6}{*}{$\mathrm{PM}_{10}$ (24 h average last year before birth) } & 27.04 & $(6.35)$ & $\mathrm{PM}_{10}(24 \mathrm{~h}$ average last year before interview) & 25.39 & $(5.65)$ \\
\hline & & & $\mathrm{CO}(24 \mathrm{~h}$ average last 3 years before interview) & 0.49 & $(0.19)$ \\
\hline & & & $\mathrm{O}_{3}(24 \mathrm{~h}$ average last 3 years before interview) & 52.54 & $(13.90)$ \\
\hline & & & $\mathrm{NO}_{2}(24 \mathrm{~h}$ average last 3 years before interview) & 31.14 & $(13.29)$ \\
\hline & & & $\mathrm{SO}_{2}(24 \mathrm{~h}$ average last 3 years before interview) & 4.92 & $(1.93)$ \\
\hline & & & $\mathrm{PM}_{10}$ (24 $\mathrm{h}$ average last 3 years before interview) & 29.56 & $(7.11)$ \\
\hline \multicolumn{6}{|l|}{ Pollutants (indoor) } \\
\hline Mother smokes $($ yes $=1)$ & 0.21 & $(0.41)$ & Mother smokes $($ yes $=1)$ & 0.26 & $(0.44)$ \\
\hline Father smokes $($ yes $=1)$ & 0.31 & $(0.46)$ & Father smokes $($ yes $=1)$ & 0.49 & $(0.50)$ \\
\hline Number of cigarettes smoked & 6.39 & $(11.47)$ & Number of cigarettes smoked & 6.20 & $(9.36)$ \\
\hline \multicolumn{6}{|l|}{ Control variables } \\
\hline Mother's education (low level) & 0.17 & $(0.38)$ & Mother's education (low level) & 0.14 & $(0.35)$ \\
\hline Mother's education (medium level) & 0.61 & $(0.49)$ & Mother's education (medium level) & 0.63 & $(0.48)$ \\
\hline Mother's education (high level) & 0.22 & $(0.42)$ & Mother's education (high level) & 0.23 & $(0.42)$ \\
\hline Mother's age (in years) & 31.20 & $(5.44)$ & Mother's age (in years) & 33.34 & $(3.95)$ \\
\hline Immigration background (yes $=1$ ) & 0.14 & $(0.35)$ & Immigration background (yes $=1)$ & 0.12 & $(0.32)$ \\
\hline Family income ( 1,000 euros $)$ & 2.39 & $(1.69)$ & Family income (1,000 euros) & 2.50 & $(1.91)$ \\
\hline Single household $($ yes $=1)$ & 0.07 & $(0.25)$ & Single household (yes $=1)$ & 0.15 & $(0.36)$ \\
\hline
\end{tabular}


Municipality size

$3.79 \quad(1.95) \quad$ Municipality size

3.74

$(0.32)$

Firstborn (yes=1)

(0.50) Firstborn (yes $=1)$

0.45

$(0.50)$

Girl (yes=1)

0.51

(0.50) Girl (yes $=1)$

0.51

$(0.50)$

Source: SOEP 2002-2007: own calculations. 
Table A3: Effects of outdoor pollution on child's health in the first year of life (various model specifications)

\begin{tabular}{|c|c|c|c|c|c|c|c|c|c|c|c|c|c|c|c|}
\hline & [1] & $\begin{array}{l}\text { CO } \\
{[2]}\end{array}$ & [3] & [1] & $\begin{array}{l}\mathrm{O}_{3} \\
{[2]} \\
\end{array}$ & [3] & [1] & $\begin{array}{c}\mathrm{NO}_{2} \\
{[2]}\end{array}$ & [3] & [1] & $\begin{array}{l}\mathrm{SO}_{2} \\
{[2]}\end{array}$ & [3] & [1] & $\begin{array}{c}\mathbf{P M}_{10} \\
{[2]}\end{array}$ & [3] \\
\hline \multicolumn{16}{|l|}{ Height } \\
\hline pollution at birth & $\begin{array}{l}-0.47 \\
(0.52)\end{array}$ & $\begin{array}{c}0.13 \\
(0.62)\end{array}$ & $\begin{array}{l}-0.09 \\
(0.55)\end{array}$ & $\begin{array}{c}0.00 \\
(0.01)\end{array}$ & $\begin{array}{c}0.01 \\
(0.01)\end{array}$ & $\begin{array}{l}-0.00 \\
(0.01)\end{array}$ & $\begin{array}{l}-0.01 \\
(0.01)\end{array}$ & $\begin{array}{l}-0.01 \\
(0.01)\end{array}$ & $\begin{array}{l}-0.01 \\
(0.01)\end{array}$ & $\begin{array}{l}-0.05 \\
(0.06)\end{array}$ & $\begin{array}{l}-0.03 \\
(0.06)\end{array}$ & $\begin{array}{c}-0.13 * * * \\
(0.05)\end{array}$ & $\begin{array}{l}0.03^{*} \\
(0.01)\end{array}$ & $\begin{array}{l}0.03 * \\
(0.02)\end{array}$ & $\begin{array}{c}0.01 \\
(0.02)\end{array}$ \\
\hline pollution during pregnancy & $\begin{array}{l}-0.38 \\
(0.49)\end{array}$ & $\begin{array}{l}-0.24 \\
(0.61)\end{array}$ & $\begin{array}{c}0.17 \\
(0.51)\end{array}$ & $\begin{array}{l}0.001 \\
(0.01)\end{array}$ & $\begin{array}{c}0.01 \\
(0.01)\end{array}$ & $\begin{array}{c}-0.02 * * \\
(0.01)\end{array}$ & $\begin{array}{l}-0.001 \\
(0.01)\end{array}$ & $\begin{array}{l}-0.01 \\
(0.01)\end{array}$ & $\begin{array}{l}-0.02 * * \\
(0.01)\end{array}$ & $\begin{array}{l}-0.03 \\
(0.04)\end{array}$ & $\begin{array}{l}-0.04 \\
(0.05)\end{array}$ & $\begin{array}{l}-0.11 * * \\
(0.04)\end{array}$ & $\begin{array}{c}0.05^{* * *} \\
(0.02)\end{array}$ & $\begin{array}{c}0.07 * * * \\
(0.02)\end{array}$ & $\begin{array}{c}0.02 \\
(0.02)\end{array}$ \\
\hline $\begin{array}{r}\text { latent pollution } \\
\text { by trimester }\end{array}$ & $\begin{array}{l}-0.06 \\
(0.12)\end{array}$ & $\begin{array}{c}0.01 \\
(0.16)\end{array}$ & $\begin{array}{c}0.12 \\
(0.14)\end{array}$ & $\begin{array}{c}0.06 \\
(0.20)\end{array}$ & $\begin{array}{c}0.38 \\
(0.26)\end{array}$ & $\begin{array}{l}-0.16 \\
(0.24)\end{array}$ & $\begin{array}{l}-0.01 \\
(0.11)\end{array}$ & $\begin{array}{l}-0.17 \\
(0.16)\end{array}$ & $\begin{array}{l}-0.26^{* *} \\
(0.13)\end{array}$ & $\begin{array}{l}-0.08 \\
(0.11)\end{array}$ & $\begin{array}{l}-0.10 \\
(0.13)\end{array}$ & $\begin{array}{l}-0.17 \\
(0.16)\end{array}$ & $\begin{array}{l}0.38^{* *} \\
(0.15)\end{array}$ & $\begin{array}{l}0.36^{* *} \\
(0.18)\end{array}$ & $\begin{array}{c}0.01 \\
(0.20)\end{array}$ \\
\hline $\begin{array}{r}\text { latent maximum pollution } \\
\text { by trimester }\end{array}$ & $\begin{array}{l}-0.07 \\
(0.12)\end{array}$ & $\begin{array}{c}0.01 \\
(0.17)\end{array}$ & $\begin{array}{c}0.06 \\
(0.14)\end{array}$ & $\begin{array}{c}0.13 \\
(0.18)\end{array}$ & $\begin{array}{l}0.38^{*} \\
(0.23)\end{array}$ & $\begin{array}{l}-0.10 \\
(0.21)\end{array}$ & $\begin{array}{c}0.01 \\
(0.11)\end{array}$ & $\begin{array}{l}-0.16 \\
(0.16)\end{array}$ & $\begin{array}{l}-0.26^{*} \\
(0.13)\end{array}$ & $\begin{array}{l}-0.04 \\
(0.13)\end{array}$ & $\begin{array}{l}-0.08 \\
(0.14)\end{array}$ & $\begin{array}{l}-0.17 \\
(0.18)\end{array}$ & $\begin{array}{c}0.42 * * \\
(0.18)\end{array}$ & $\begin{array}{l}0.49 * * \\
(0.22)\end{array}$ & $\begin{array}{c}0.27 \\
(0.23)\end{array}$ \\
\hline \multicolumn{16}{|l|}{ Fetal Growth } \\
\hline pollution at birth & $\begin{array}{l}-0.02 \\
(2.08)\end{array}$ & $\begin{array}{c}2.72 \\
(2.88)\end{array}$ & $\begin{array}{c}-7.27 * * * \\
(2.78)\end{array}$ & $\begin{array}{c}-0.07 * * \\
(0.03)\end{array}$ & $\begin{array}{l}-0.03 \\
(0.04)\end{array}$ & $\begin{array}{l}-0.06 \\
(0.04)\end{array}$ & $\begin{array}{l}0.003 \\
(0.03)\end{array}$ & $\begin{array}{c}0.00 \\
(0.03)\end{array}$ & $\begin{array}{c}0.03 \\
(0.04)\end{array}$ & $\begin{array}{l}-0.20 \\
(0.20)\end{array}$ & $\begin{array}{l}-0.14 \\
(0.22)\end{array}$ & $\begin{array}{l}-0.34 \\
(0.24)\end{array}$ & $\begin{array}{c}0.05 \\
(0.06)\end{array}$ & $\begin{array}{c}0.09 \\
(0.07)\end{array}$ & $\begin{array}{r}0.18 * * \\
(0.08)\end{array}$ \\
\hline pollution during pregnancy & $\begin{array}{l}0.004 \\
(2.06)\end{array}$ & $\begin{array}{l}1.31 \\
(2.70)\end{array}$ & $\begin{array}{l}-4.57 * \\
(2.62)\end{array}$ & $\begin{array}{l}-0.07 * \\
(0.04)\end{array}$ & $\begin{array}{l}-0.03 \\
(0.04)\end{array}$ & $\begin{array}{l}-0.08^{*} \\
(0.05)\end{array}$ & $\begin{array}{l}0.009 \\
(0.03)\end{array}$ & $\begin{array}{l}-0.00 \\
(0.03)\end{array}$ & $\begin{array}{c}0.01 \\
(0.04)\end{array}$ & $\begin{array}{l}-0.11 \\
(0.17)\end{array}$ & $\begin{array}{l}-0.16 \\
(0.19)\end{array}$ & $\begin{array}{l}-0.18 \\
(0.23)\end{array}$ & $\begin{array}{c}0.07 \\
(0.07)\end{array}$ & $\begin{array}{c}0.14 \\
(0.09)\end{array}$ & $\begin{array}{l}-0.01 \\
(0.09)\end{array}$ \\
\hline $\begin{array}{r}\text { latent pollution level } \\
\text { by trimester }\end{array}$ & $\begin{array}{c}0.32 \\
(0.51)\end{array}$ & $\begin{array}{c}0.55 \\
(0.69)\end{array}$ & $\begin{array}{l}-1.34 * \\
(0.73)\end{array}$ & $\begin{array}{l}-1.73 * * \\
(0.83)\end{array}$ & $\begin{array}{l}-0.65 \\
(0.94)\end{array}$ & $\begin{array}{l}-2.15^{*} \\
(1.19)\end{array}$ & $\begin{array}{c}0.23 \\
(0.46)\end{array}$ & $\begin{array}{c}0.05 \\
(0.58)\end{array}$ & $\begin{array}{l}-0.22 \\
(0.66)\end{array}$ & $\begin{array}{l}-0.07 \\
(0.43)\end{array}$ & $\begin{array}{l}-0.26 \\
(0.55)\end{array}$ & $\begin{array}{c}0.16 \\
(0.81)\end{array}$ & $\begin{array}{c}0.23 \\
(0.58)\end{array}$ & $\begin{array}{c}0.53 \\
(0.79)\end{array}$ & $\begin{array}{c}0.63 \\
(0.91)\end{array}$ \\
\hline $\begin{array}{l}\text { latent maximum pollution } \\
\text { by trimester } \\
\text { Weight }\end{array}$ & $\begin{array}{c}0.26 \\
(0.52)\end{array}$ & $\begin{array}{c}0.42 \\
(0.71)\end{array}$ & $\begin{array}{l}-1.44 * \\
(0.74)\end{array}$ & $\begin{array}{l}-1.20^{*} \\
(0.71)\end{array}$ & $\begin{array}{l}-0.15 \\
(0.84)\end{array}$ & $\begin{array}{l}-1.92 * \\
(1.02)\end{array}$ & $\begin{array}{c}0.28 \\
(0.47)\end{array}$ & $\begin{array}{c}0.11 \\
(0.58)\end{array}$ & $\begin{array}{l}-0.17 \\
(0.67)\end{array}$ & $\begin{array}{c}0.02 \\
(0.50)\end{array}$ & $\begin{array}{l}-0.18 \\
(0.61)\end{array}$ & $\begin{array}{c}0.14 \\
(0.90)\end{array}$ & $\begin{array}{c}0.10 \\
(0.69)\end{array}$ & $\begin{array}{c}0.73 \\
(0.95)\end{array}$ & $\begin{array}{c}1.38 \\
(1.00)\end{array}$ \\
\hline pollution at birth & $\begin{array}{c}5.14 \\
(93.05)\end{array}$ & $\begin{array}{c}103.45 \\
(120.69)\end{array}$ & $\begin{array}{c}-289.25^{* *} \\
(112.81)\end{array}$ & $\begin{array}{l}-2.28 \\
(1.41)\end{array}$ & $\begin{array}{l}-0.20 \\
(1.64)\end{array}$ & $\begin{array}{l}-2.57 \\
(1.86)\end{array}$ & $\begin{array}{l}-0.37 \\
(1.25)\end{array}$ & $\begin{array}{l}-0.49 \\
(1.44)\end{array}$ & $\begin{array}{c}0.39 \\
(1.48)\end{array}$ & $\begin{array}{l}-9.24 \\
(8.96)\end{array}$ & $\begin{array}{l}-4.81 \\
(9.57)\end{array}$ & $\begin{array}{l}-15.87 \\
(10.04)\end{array}$ & $\begin{array}{c}2.52 \\
(2.58)\end{array}$ & $\begin{array}{l}4.85 \\
(2.99)\end{array}$ & $\begin{array}{l}8.06 * * \\
(3.33)\end{array}$ \\
\hline pollution during pregnancy & $\begin{array}{l}-11.72 \\
(93.35)\end{array}$ & $\begin{array}{c}17.12 \\
(119.93)\end{array}$ & $\begin{array}{l}-190.11^{*} \\
(106.31)\end{array}$ & $\begin{array}{l}-2.25 \\
(1.79)\end{array}$ & $\begin{array}{l}-0.50 \\
(1.78)\end{array}$ & $\begin{array}{l}-3.26^{*} \\
(1.91)\end{array}$ & $\begin{array}{l}-0.11 \\
(1.26)\end{array}$ & $\begin{array}{l}-0.59 \\
(1.49)\end{array}$ & $\begin{array}{l}-0.71 \\
(1.57)\end{array}$ & $\begin{array}{l}-4.39 \\
(7.47)\end{array}$ & $\begin{array}{l}-4.82 \\
(8.28)\end{array}$ & $\begin{array}{l}-5.38 \\
(9.48)\end{array}$ & $\begin{array}{c}4.28 \\
(3.34)\end{array}$ & $\begin{array}{l}7.13^{*} \\
(3.87)\end{array}$ & $\begin{array}{c}2.64 \\
(3.94)\end{array}$ \\
\hline $\begin{array}{r}\text { latent pollution } \\
\text { by trimester }\end{array}$ & $\begin{array}{c}8.94 \\
(23.34)\end{array}$ & $\begin{array}{c}13.42 \\
(31.02)\end{array}$ & $\begin{array}{l}-54.47^{*} \\
(29.53)\end{array}$ & $\begin{array}{l}-57.93 \\
(36.84)\end{array}$ & $\begin{array}{l}-2.08 \\
(43.15)\end{array}$ & $\begin{array}{l}-68.78 \\
(49.67)\end{array}$ & $\begin{array}{c}1.27 \\
(20.82)\end{array}$ & $\begin{array}{l}-10.12 \\
(25.22)\end{array}$ & $\begin{array}{l}-23.94 \\
(27.02)\end{array}$ & $\begin{array}{c}-8.83 \\
(19.46)\end{array}$ & $\begin{array}{c}-4.09 \\
(24.06)\end{array}$ & $\begin{array}{c}19.33 \\
(33.81)\end{array}$ & $\begin{array}{l}23.06 \\
(26.41)\end{array}$ & $\begin{array}{c}29.98 \\
(35.92)\end{array}$ & $\begin{array}{c}28.61 \\
(38.01)\end{array}$ \\
\hline $\begin{array}{l}\text { latent maximum pollution } \\
\text { by trimester } \\
\text { Disorder }\end{array}$ & $\begin{array}{c}8.37 \\
(24.11)\end{array}$ & $\begin{array}{c}10.23 \\
(31.56)\end{array}$ & $\begin{array}{c}-62.12 * * \\
(29.88)\end{array}$ & $\begin{array}{l}-34.13 \\
(31.95)\end{array}$ & $\begin{array}{c}19.92 \\
(38.31)\end{array}$ & $\begin{array}{l}-53.54 \\
(42.87)\end{array}$ & $\begin{array}{c}3.63 \\
(21.02)\end{array}$ & $\begin{array}{c}-8.02 \\
(25.41)\end{array}$ & $\begin{array}{l}-22.51 \\
(27.70)\end{array}$ & $\begin{array}{c}-5.42 \\
(22.47)\end{array}$ & $\begin{array}{c}-1.24 \\
(26.30)\end{array}$ & $\begin{array}{c}14.51 \\
(37.50)\end{array}$ & $\begin{array}{c}15.06 \\
(31.70)\end{array}$ & $\begin{array}{c}35.74 \\
(43.32)\end{array}$ & $\begin{array}{c}52.48 \\
(42.08) \\
(4)\end{array}$ \\
\hline $\begin{array}{l}\text { Disorder } \\
\quad \text { pollution at birth }\end{array}$ & $\begin{array}{c}0.025 \\
(0.029)\end{array}$ & $\begin{array}{c}0.004 \\
(0.057)\end{array}$ & $\begin{array}{c}-0.03 \\
(0.063)\end{array}$ & $\begin{array}{l}-0.00 \\
(0.001)\end{array}$ & $\begin{array}{l}-0.00 \\
(0.001)\end{array}$ & $\begin{array}{l}0.002 * \\
(0.001)\end{array}$ & $\begin{array}{l}-0.00 \\
(0.000)\end{array}$ & $\begin{array}{c}0.001 \\
(0.001)\end{array}$ & $\begin{array}{c}0.001 \\
(0.001)\end{array}$ & $\begin{array}{c}0.00 \\
(0.003)\end{array}$ & $\begin{array}{l}-0.003 \\
(0.004)\end{array}$ & $\begin{array}{c}0.017 * * * \\
(0.006)\end{array}$ & $\begin{array}{l}-0.00 \\
(0.001)\end{array}$ & $\begin{array}{c}0.001 \\
(0.002)\end{array}$ & $\begin{array}{l}-0.003 \\
(0.002)\end{array}$ \\
\hline pollution during pregnancy & $\begin{array}{c}0.038 \\
(0.031)\end{array}$ & $\begin{array}{c}0.039 \\
(0.054)\end{array}$ & $\begin{array}{c}0.08 \\
(0.057)\end{array}$ & $\begin{array}{c}-0.002 * * * \\
(0.001)\end{array}$ & $\begin{array}{c}-0.001^{* *} \\
(0.001)\end{array}$ & $\begin{array}{l}0.002^{* *} \\
(0.001)\end{array}$ & $\begin{array}{l}-0.00 \\
(0.000)\end{array}$ & $\begin{array}{c}0.000 \\
(0.001)\end{array}$ & $\begin{array}{c}0.001 \\
(0.001)\end{array}$ & $\begin{array}{l}-0.00 \\
(0.002)\end{array}$ & $\begin{array}{l}-0.002 \\
(0.003)\end{array}$ & $\begin{array}{c}0.003 \\
(0.005)\end{array}$ & $\begin{array}{c}0.00 \\
(0.001)\end{array}$ & $\begin{array}{c}0.001 \\
(0.002)\end{array}$ & $\begin{array}{c}0.000 \\
(0.002)\end{array}$ \\
\hline $\begin{array}{r}\text { latent pollution } \\
\text { by trimester }\end{array}$ & $\begin{array}{l}0.014^{*} \\
(0.008)\end{array}$ & $\begin{array}{c}0.015 \\
(0.014)\end{array}$ & $\begin{array}{c}0.02 \\
(0.016)\end{array}$ & $\begin{array}{l}-0.03 * * \\
(0.013)\end{array}$ & $\begin{array}{l}-0.03 * \\
(0.017)\end{array}$ & $\begin{array}{c}0.023 \\
(0.026)\end{array}$ & $\begin{array}{l}-0.001 \\
(0.007)\end{array}$ & $\begin{array}{c}0.007 \\
(0.010)\end{array}$ & $\begin{array}{c}0.021 \\
(0.014)\end{array}$ & $\begin{array}{c}0.001 \\
(0.007)\end{array}$ & $\begin{array}{l}-0.007 \\
(0.009)\end{array}$ & $\begin{array}{l}0.040 * * \\
(0.017)\end{array}$ & $\begin{array}{c}0.001 \\
(0.009)\end{array}$ & $\begin{array}{c}0.008 \\
(0.011)\end{array}$ & $\begin{array}{c}0.001 \\
(0.023)\end{array}$ \\
\hline $\begin{array}{r}\text { latent maximum pollution } \\
\text { by trimester }\end{array}$ & $\begin{array}{l}0.015^{*} \\
(0.008) \\
\end{array}$ & $\begin{array}{c}0.017 \\
(0.014) \\
\end{array}$ & $\begin{array}{c}0.02 \\
(0.016) \\
\end{array}$ & $\begin{array}{l}-0.03 * * \\
(0.011) \\
\end{array}$ & $\begin{array}{l}-0.03 * \\
(0.016) \\
\end{array}$ & $\begin{array}{c}0.032 \\
(0.022)\end{array}$ & $\begin{array}{l}-0.001 \\
(0.007)\end{array}$ & $\begin{array}{c}0.009 \\
(0.011) \\
\end{array}$ & $\begin{array}{l}0.024 * \\
(0.014) \\
\end{array}$ & $\begin{array}{c}0.01 \\
(0.008)\end{array}$ & $\begin{array}{l}-0.003 \\
(0.010) \\
\end{array}$ & $\begin{array}{c}0.057^{* * *} \\
(0.019) \\
\end{array}$ & $\begin{array}{c}0.003 \\
(0.010) \\
\end{array}$ & $\begin{array}{c}0.003 \\
(0.013) \\
\end{array}$ & $\begin{array}{r}0.007 \\
(0.026) \\
\end{array}$ \\
\hline
\end{tabular}

Source: SOEP 2002-2007: own calculations. 
Note: Standard errors are in parenthesis. *indicates statistical significance at the $10 \%$ level, ** at the $5 \%$ level, *** at the $1 \%$ level. All regressions include indicators of mother's education, age, income, municipality size, immigration background, gender of the child, birth order, months and year dummies. (1) OLS, (2) Zip-code fixed effect models, (3)

Zip- code and family fixed effect models. Sample size varies between 1,154 and 1,268 observations. 
Table A4: Effects of outdoor and indoor pollution on child's health in the first year of life (various model specifications)

\begin{tabular}{|c|c|c|c|c|c|c|c|c|c|c|c|c|c|c|c|}
\hline & \multicolumn{3}{|c|}{${ }^{\mathrm{i}} \mathbf{C O}$} & \multicolumn{3}{|c|}{${ }^{\mathrm{i}} \mathbf{O}_{3}$} & \multicolumn{3}{|c|}{${ }^{\mathrm{i}} \mathrm{NO}_{2}$} & \multicolumn{3}{|c|}{${ }^{\mathrm{i}} \mathrm{SO}_{2}$} & \multicolumn{3}{|c|}{${ }^{\mathbf{i}} \mathbf{P} \mathbf{M}_{10}$} \\
\hline & [1] & [2] & [3] & [1] & [2] & [3] & [1] & [2] & [3] & [1] & [2] & [3] & [1] & [2] & [3] \\
\hline \multicolumn{16}{|l|}{ Height } \\
\hline \multirow[t]{2}{*}{ outdoor (latent) ${ }^{\mathrm{i}}$} & -0.04 & 0.08 & -0.10 & $-0.30 * *$ & -0.18 & -0.49 & -0.07 & -0.25 & $-0.26^{*}$ & -0.17 & -0.14 & $-0.34 * *$ & $0.36^{* *}$ & 0.29 & -0.25 \\
\hline & $(0.13)$ & $(0.17)$ & $(0.15)$ & $(0.14)$ & $(0.17)$ & $(0.30)$ & $(0.11)$ & $(0.16)$ & $(0.14)$ & $(0.12)$ & $(0.14)$ & $(0.16)$ & $(0.16)$ & $(0.19)$ & $(0.21)$ \\
\hline \multirow[t]{2}{*}{ indoor (latent) } & $-0.39 * *$ & $-0.37 *$ & 0.20 & 0.19 & 0.40 & -0.05 & $-0.33 * *$ & $-0.32 *$ & -0.11 & $-0.31 * *$ & -0.21 & -0.03 & $-0.46^{* *}$ & $-0.59 * *$ & $-1.11 * * *$ \\
\hline & $(0.16)$ & $(0.20)$ & $(0.35)$ & $(0.20)$ & $(0.27)$ & $(0.25)$ & $(0.15)$ & $(0.18)$ & $(0.33)$ & $(0.16)$ & $(0.20$ & $(0.31)$ & $(0.18)$ & $(0.25)$ & $(0.33)$ \\
\hline \multirow{3}{*}{$\begin{array}{l}\text { Fetal growth } \\
\text { outdoor (latent) }^{\mathrm{i}}\end{array}$} & & & & & & & & & & & & & & & \\
\hline & 0.52 & 0.85 & $-1.65 * *$ & $-1.64 * * *$ & -1.05 & -2.16 & 0.03 & -0.15 & -0.29 & -0.21 & -0.42 & -0.20 & 0.02 & 0.40 & 0.65 \\
\hline & $(0.48)$ & $(0.70)$ & $(0.79)$ & $(0.60)$ & $(0.70)$ & $(1.59)$ & $(0.48)$ & $(0.61)$ & $(0.72)$ & $(0.44)$ & $(0.63)$ & $(0.87)$ & $(0.58)$ & $(0.80)$ & $(0.96)$ \\
\hline \multirow[t]{2}{*}{ indoor (latent) } & $-1.81 * * *$ & -1.25 & -0.46 & -1.03 & -0.53 & -1.82 & $-1.49 * *$ & -1.19 & 0.40 & $-1.38 * *$ & -0.64 & -0.09 & $-2.34 * * *$ & $-2.24 * *$ & $-3.82 * *$ \\
\hline & $(0.66)$ & $(0.86)$ & $(1.91)$ & $(0.84)$ & $(1.01)$ & $(1.28)$ & $(0.61)$ & $(0.75)$ & $(1.77)$ & $(0.67)$ & $(0.84)$ & $(1.72)$ & $(0.74)$ & $(0.98)$ & $(1.55)$ \\
\hline \multirow{3}{*}{$\begin{array}{l}\text { Birth weight } \\
\text { outdoor (latent) }^{\mathrm{i}}\end{array}$} & & & & & & & & & & & & & & & \\
\hline & 19.86 & 25.08 & $-77.92 * *$ & $-68.60 * * *$ & -46.15 & -62.17 & -10.21 & -19.22 & -22.04 & -14.65 & -6.61 & -8.35 & 11.20 & 11.17 & 10.27 \\
\hline & $(22.08)$ & (31.82) & $(32.81)$ & $(25.77)$ & $(30.70)$ & $(65.50)$ & $(21.12)$ & $(26.37)$ & $(30.20)$ & $(20.00)$ & $(26.80)$ & (37.04) & $(26.99)$ & $(35.67)$ & $(40.92)$ \\
\hline \multirow[t]{2}{*}{ indoor (latent) } & $-77.13^{* * *}$ & $-62.54^{*}$ & 23.30 & -29.45 & 12.56 & -51.43 & $-67.86 * * *$ & $-62.37^{*}$ & 51.02 & $-57.15^{* *}$ & -33.79 & 35.73 & $-101.86^{* * *}$ & $-114.40 * *$ & $\begin{array}{c}- \\
206.77 * * \\
*\end{array}$ \\
\hline & $(28.05)$ & (37.90) & $(77.23)$ & $(37.74)$ & $(46.37)$ & $(53.77)$ & $(25.91)$ & $(32.64)$ & $(72.45)$ & $(28.57)$ & $(35.79)$ & $(71.80)$ & $(32.21)$ & $(44.41)$ & $(65.97)$ \\
\hline \multirow{3}{*}{$\begin{array}{l}\text { Disorder } \\
\text { outdoor (latent) }\end{array}$} & & & & & & & & & & & & & & & \\
\hline & $0.015^{*}$ & 0.012 & $0.028^{*}$ & -0.005 & -0.001 & -0.013 & -0.000 & 0.011 & $0.026^{*}$ & 0.004 & 0.001 & $0.044 * *$ & 0.002 & 0.006 & 0.020 \\
\hline & $(0.008)$ & $(0.015)$ & $(0.017)$ & $(0.011)$ & $(0.013)$ & $(0.033)$ & $(0.007)$ & $(0.011)$ & $(0.014)$ & $(0.007)$ & $(0.009)$ & $(0.018)$ & $(0.010)$ & $(0.012)$ & $(0.024)$ \\
\hline \multirow[t]{2}{*}{ indoor (latent) } & 0.001 & 0.014 & -0.045 & $-0.032 * *$ & $-0.03 *$ & 0.021 & 0.005 & 0.009 & -0.047 & 0.004 & 0.011 & $-0.071 * *$ & 0.001 & 0.003 & 0.001 \\
\hline & $(0.011)$ & $(0.015)$ & $(0.039)$ & $(0.014)$ & $(0.018)$ & $(0.027)$ & $(0.011)$ & $(0.014)$ & $(0.035)$ & $(0.013)$ & $(0.016)$ & $(0.035)$ & $(0.014)$ & $(0.017)$ & $(0.039)$ \\
\hline
\end{tabular}

Source: SOEP 2002-2007: own calculations.

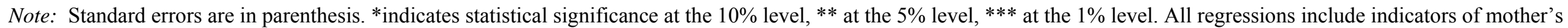
education, age, income, municipality size, immigration background, gender of the child, birth order, months and year dummies. (1) OLS, (2) Zip-code fixed effect models, (3)

Zip-code and family fixed effect models. Sample size varies between 1,154 and 1,268 observations. 
Table A5: Effects of indoor pollution on child's health in the first year of life

\begin{tabular}{lccccc}
\hline \hline & Mother smokes & Father smokes & \multicolumn{2}{c}{ Both smoke } & $\begin{array}{c}\text { Total number of } \\
\text { cigarettes } \\
\text { smoked }\end{array}$ \\
\hline \hline Birth height & $-0.81^{* * *}$ & & Mother & Father & -0.02 \\
& $(0.27)$ & -0.13 & $-1.10^{* * *}$ & 0.15 & $(0.01)$ \\
Fetal growth & $-3.17^{* *}$ & $(0.26)$ & $(0.37)$ & $(0.29)$ & $-0.08^{* *}$ \\
& $(1.11)$ & -1.59 & $-3.17^{*}$ & $-0.91^{*}$ & $(0.04)$ \\
Birth weight & $-145.42^{* *}$ & $(1.09)$ & $(1.36)$ & $(1.19)$ & $-3.84^{* *}$ \\
& $(48.40)$ & -72.7 & $-175.50^{* *}$ & $-34.01 * *$ & $(1.55)$ \\
Disorder & 0.007 & $(49.37)$ & $(61.07)$ & $(53.69)$ & 0.000 \\
& $(0.019)$ & 0.002 & 0.001 & 0.008 & $(0.001)$ \\
\hline \hline
\end{tabular}

Source: SOEP 2002-2007: own calculations.

Note: Standard errors are in parenthesis. *indicates statistical significance at the $10 \%$ level, ** at the $5 \%$ level, *** at the $1 \%$ level. All regressions include indicators of mother's education, age, income, municipality size, immigration background, gender of the child, birth order, month and year dummies. Sample size varies between 1,154 and 1,268 observations. 
Table A6: Effects of outdoor pollution on child's health at two to three years of age (various model specifications)

\begin{tabular}{|c|c|c|c|c|c|c|c|c|c|c|c|c|c|c|c|}
\hline & [1] & $\begin{array}{l}\text { CO } \\
\text { [2] }\end{array}$ & [3] & [1] & $\begin{array}{l}\mathbf{O}_{3} \\
{[2]}\end{array}$ & [3] & [1] & $\begin{array}{c}\mathrm{NO}_{2} \\
\text { [2] }\end{array}$ & [3] & [1] & $\begin{array}{l}\mathrm{SO}_{2} \\
\text { [2] }\end{array}$ & [3] & [1] & $\begin{array}{c}\mathbf{P M}_{10} \\
\text { [2] }\end{array}$ & [3] \\
\hline \multicolumn{16}{|l|}{ Bronchitis } \\
\hline mean year pollution & $\begin{array}{c}-0.06 \\
(0.07)\end{array}$ & $\begin{array}{c}-0.07 \\
(0.10)\end{array}$ & $\begin{array}{l}-0.06 \\
(0.14)\end{array}$ & $\begin{array}{c}0.00^{* *} \\
(0.00)\end{array}$ & $\begin{array}{c}0.00 \\
(0.00)\end{array}$ & $\begin{array}{c}0.00 \\
(0.00)\end{array}$ & $\begin{array}{c}-0.00 \\
(0.00)\end{array}$ & $\begin{array}{c}0.00 \\
(0.00)\end{array}$ & $\begin{array}{c}-0.00 \\
(0.00)\end{array}$ & $\begin{array}{c}-0.00 \\
(0.01)\end{array}$ & $\begin{array}{c}-0.00 \\
(0.01)\end{array}$ & $\begin{array}{c}0.00 \\
(0.02)\end{array}$ & $\begin{array}{l}-0.0^{*} \\
(0.00)\end{array}$ & $\begin{array}{c}-0.00 \\
(0.00)\end{array}$ & $\begin{array}{c}0.01 \\
(0.00)\end{array}$ \\
\hline Pollution intensity (latent) & $\begin{array}{c}-0.01 \\
(0.01)\end{array}$ & $\begin{array}{c}-0.02 \\
(0.02)\end{array}$ & $\begin{array}{l}-0.03 \\
(0.03)\end{array}$ & $\begin{array}{c}0.02 * * \\
(0.01)\end{array}$ & $\begin{array}{c}0.02 \\
(0.02)\end{array}$ & $\begin{array}{c}0.02 \\
(0.03)\end{array}$ & $\begin{array}{c}-0.01 \\
(0.01)\end{array}$ & $\begin{array}{c}0.00 \\
(0.02)\end{array}$ & $\begin{array}{c}-0.03 \\
(0.03)\end{array}$ & $\begin{array}{c}-0.01 \\
(0.01)\end{array}$ & $\begin{array}{c}-0.00 \\
(0.02)\end{array}$ & $\begin{array}{c}0.01 \\
(0.03)\end{array}$ & $\begin{array}{c}-0.02 \\
(0.02)\end{array}$ & $\begin{array}{c}-0.01 \\
(0.03)\end{array}$ & $\begin{array}{l}0.06^{*} \\
(0.03)\end{array}$ \\
\hline Pollution intensity (latent) at interview & $\begin{array}{c}-0.01 \\
(0.01)\end{array}$ & $\begin{array}{c}-0.02 \\
(0.02)\end{array}$ & $\begin{array}{l}-0.02 \\
(0.03)\end{array}$ & $\begin{array}{c}0.02 * * \\
(0.01)\end{array}$ & $\begin{array}{c}0.01 \\
(0.01)\end{array}$ & $\begin{array}{c}0.03 \\
(0.03)\end{array}$ & $\begin{array}{c}-0.01 \\
(0.01)\end{array}$ & $\begin{array}{c}0.00 \\
(0.02)\end{array}$ & $\begin{array}{l}-0.03 \\
(0.03)\end{array}$ & $\begin{array}{l}-0.01 \\
(0.01)\end{array}$ & $\begin{array}{c}-0.01 \\
(0.02)\end{array}$ & $\begin{array}{c}0.01 \\
(0.03)\end{array}$ & $\begin{array}{c}-0.03 \\
(0.02)\end{array}$ & $\begin{array}{c}-0.02 \\
(0.03)\end{array}$ & $\begin{array}{c}0.04 \\
(0.03)\end{array}$ \\
\hline Mean pollution at interview & $\begin{array}{c}-0.02 \\
(0.06)\end{array}$ & $\begin{array}{c}-0.08 \\
(0.10)\end{array}$ & $\begin{array}{l}-0.04 \\
(0.15)\end{array}$ & $\begin{array}{l}0.00^{*} \\
(0.00)\end{array}$ & $\begin{array}{c}0.00 \\
(0.00)\end{array}$ & $\begin{array}{c}0.00 \\
(0.00)\end{array}$ & $\begin{array}{c}-0.00 \\
(0.00)\end{array}$ & $\begin{array}{c}0.00 \\
(0.00)\end{array}$ & $\begin{array}{l}-0.00 \\
(0.00)\end{array}$ & $\begin{array}{c}0.00 \\
(0.00)\end{array}$ & $\begin{array}{c}0.00 \\
(0.01)\end{array}$ & $\begin{array}{c}0.01 \\
(0.01)\end{array}$ & $\begin{array}{l}-0.00 \\
(0.00)\end{array}$ & $\begin{array}{c}-0.00 \\
(0.00)\end{array}$ & $\begin{array}{c}0.00 \\
(0.00)\end{array}$ \\
\hline three-year mean & $\begin{array}{c}-0.07 \\
(0.07)\end{array}$ & $\begin{array}{c}-0.17 \\
(0.11)\end{array}$ & $\begin{array}{l}-0.23 \\
(0.20)\end{array}$ & $\begin{array}{c}0.00^{* *} \\
(0.00)\end{array}$ & $\begin{array}{c}0.00 \\
(0.00)\end{array}$ & $\begin{array}{l}0.01 * \\
(0.00)\end{array}$ & $\begin{array}{c}-0.00 \\
(0.00)\end{array}$ & $\begin{array}{c}-0.00 \\
(0.00)\end{array}$ & $\begin{array}{c}-0.00 \\
(0.00)\end{array}$ & $\begin{array}{l}-0.00 \\
(0.00)\end{array}$ & $\begin{array}{c}0.00 \\
(0.01)\end{array}$ & $\begin{array}{c}0.01 \\
(0.02)\end{array}$ & $\begin{array}{c}-0.00 \\
(0.00)\end{array}$ & $\begin{array}{c}-0.00 \\
(0.00)\end{array}$ & $\begin{array}{c}-0.00 \\
(0.00)\end{array}$ \\
\hline \multicolumn{16}{|l|}{ Croup syndrome } \\
\hline mean year pollution & $\begin{array}{c}0.07 \\
(0.06)\end{array}$ & $\begin{array}{c}0.06 \\
(0.09)\end{array}$ & $\begin{array}{l}-0.22 \\
(0.18)\end{array}$ & $\begin{array}{l}-0.00 \\
(0.00)\end{array}$ & $\begin{array}{c}0.00 \\
(0.00)\end{array}$ & $\begin{array}{c}0.00 \\
(0.00)\end{array}$ & $\begin{array}{c}-0.00 \\
(0.00)\end{array}$ & $\begin{array}{c}-0.00 \\
(0.00)\end{array}$ & $\begin{array}{c}-0.00 \\
(0.00)\end{array}$ & $\begin{array}{c}-0.00 \\
(0.01)\end{array}$ & $\begin{array}{c}-0.0 \\
(0.01)\end{array}$ & $\begin{array}{l}-0.03 \\
(0.02)\end{array}$ & $\begin{array}{c}-0.00 \\
(0.00)\end{array}$ & $\begin{array}{l}-0.00 \\
(0.00)\end{array}$ & $\begin{array}{c}-0.01 \\
(0.01)\end{array}$ \\
\hline Pollution intensity (latent) & $\begin{array}{c}0.01 \\
(0.01)\end{array}$ & $\begin{array}{c}0.01 \\
(0.02)\end{array}$ & $\begin{array}{l}-0.05 \\
(0.04)\end{array}$ & $\begin{array}{c}0.00 \\
(0.01)\end{array}$ & $\begin{array}{c}0.02 \\
(0.02)\end{array}$ & $\begin{array}{c}0.01 \\
(0.04)\end{array}$ & $\begin{array}{c}0.00 \\
(0.01)\end{array}$ & $\begin{array}{c}-0.02 \\
(0.02)\end{array}$ & $\begin{array}{c}-0.02 \\
(0.04)\end{array}$ & $\begin{array}{c}-0.00 \\
(0.01)\end{array}$ & $\begin{array}{c}-0.01 \\
(0.02)\end{array}$ & $\begin{array}{c}-0.11^{* *} \\
(0.05)\end{array}$ & $\begin{array}{c}-0.02 \\
(0.01)\end{array}$ & $\begin{array}{c}0.01 \\
(0.02)\end{array}$ & $\begin{array}{c}0.06 \\
(0.08)\end{array}$ \\
\hline Pollution intensity (latent) at interview & $\begin{array}{c}0.01 \\
(0.01)\end{array}$ & $\begin{array}{c}0.01 \\
(0.02)\end{array}$ & $\begin{array}{l}-0.04 \\
(0.04)\end{array}$ & $\begin{array}{l}-0.00 \\
(0.01)\end{array}$ & $\begin{array}{c}0.00 \\
(0.01)\end{array}$ & $\begin{array}{c}0.03 \\
(0.04)\end{array}$ & $\begin{array}{l}-0.00 \\
(0.01)\end{array}$ & $\begin{array}{l}-0.01 \\
(0.02)\end{array}$ & $\begin{array}{l}-0.02 \\
(0.04)\end{array}$ & $\begin{array}{l}-0.00 \\
(0.01)\end{array}$ & $\begin{array}{c}-0.01 \\
(0.02)\end{array}$ & $\begin{array}{l}-0.07 \\
(0.05)\end{array}$ & $\begin{array}{l}-0.01 \\
(0.02)\end{array}$ & $\begin{array}{l}-0.00 \\
(0.03)\end{array}$ & $\begin{array}{c}0.04 \\
(0.07)\end{array}$ \\
\hline Mean pollution at interview & $\begin{array}{c}0.05 \\
(0.05)\end{array}$ & $\begin{array}{c}0.04 \\
(0.08)\end{array}$ & $\begin{array}{l}-0.18 \\
(0.18)\end{array}$ & $\begin{array}{c}0.00 \\
(0.00)\end{array}$ & $\begin{array}{c}0.00 \\
(0.00)\end{array}$ & $\begin{array}{l}-0.00 \\
(0.00)\end{array}$ & $\begin{array}{c}0.00 \\
(0.00)\end{array}$ & $\begin{array}{c}-0.00 \\
(0.00)\end{array}$ & $\begin{array}{c}-0.00 \\
(0.00)\end{array}$ & $\begin{array}{c}0.00 \\
(0.00)\end{array}$ & $\begin{array}{c}0.00 \\
(0.01)\end{array}$ & $\begin{array}{c}-0.02 \\
(0.02)\end{array}$ & $\begin{array}{c}-0.00 \\
(0.00)\end{array}$ & $\begin{array}{l}-0.00 \\
(0.00)\end{array}$ & $\begin{array}{c}0.07 \\
(0.02)\end{array}$ \\
\hline three-years mean & $\begin{array}{c}0.04 \\
(0.05)\end{array}$ & $\begin{array}{c}-0.03 \\
(0.11)\end{array}$ & $\begin{array}{c}-0.26 \\
(0.25)\end{array}$ & $\begin{array}{c}0.00 \\
(0.00)\end{array}$ & $\begin{array}{c}0.00 \\
(0.00)\end{array}$ & $\begin{array}{c}0.00 \\
(0.00)\end{array}$ & $\begin{array}{c}0.00 \\
(0.00)\end{array}$ & $\begin{array}{c}-0.00 \\
(0.00)\end{array}$ & $\begin{array}{c}0.00 \\
(0.00)\end{array}$ & $\begin{array}{c}0.00 \\
(0.00)\end{array}$ & $\begin{array}{c}0.02 \\
(0.01)\end{array}$ & $\begin{array}{c}0.01 \\
(0.02)\end{array}$ & $\begin{array}{c}-0.00 \\
(0.00)\end{array}$ & $\begin{array}{c}-0.01 \\
(0.00)\end{array}$ & $\begin{array}{c}0.02 \\
(0.01)\end{array}$ \\
\hline \multicolumn{16}{|l|}{ Respiratory disease } \\
\hline mean year pollution & $\begin{array}{c}-0.07 \\
(0.08)\end{array}$ & $\begin{array}{c}-0.09 \\
(0.13)\end{array}$ & $\begin{array}{c}-0.03 \\
(0.19)\end{array}$ & $\begin{array}{c}0.00^{* *} \\
(0.00)\end{array}$ & $\begin{array}{c}0.00 \\
(0.00)\end{array}$ & $\begin{array}{c}0.00 \\
(0.00)\end{array}$ & $\begin{array}{c}-0.0 \\
(0.00)\end{array}$ & $\begin{array}{c}0.00 \\
(0.00)\end{array}$ & $\begin{array}{c}-0.00 \\
(0.00)\end{array}$ & $\begin{array}{l}-0.01 * \\
(0.01)\end{array}$ & $\begin{array}{c}-0.01 \\
(0.01)\end{array}$ & $\begin{array}{c}-0.00 \\
(0.02)\end{array}$ & $\begin{array}{c}-0.01 \\
(0.00)\end{array}$ & $\begin{array}{c}-0.0 \\
(0.01)\end{array}$ & $\begin{array}{l}0.02 * \\
(0.01)\end{array}$ \\
\hline Pollution intensity (latent) & $\begin{array}{c}-0.01 \\
(0.02)\end{array}$ & $\begin{array}{c}-0.04 \\
(0.02)\end{array}$ & $\begin{array}{c}-0.03 \\
(0.04)\end{array}$ & $\begin{array}{c}0.04 * * \\
(0.01)\end{array}$ & $\begin{array}{c}0.03 \\
(0.02)\end{array}$ & $\begin{array}{l}-0.00 \\
(0.04)\end{array}$ & $\begin{array}{c}-0.00 \\
(0.01)\end{array}$ & $\begin{array}{c}0.02 \\
(0.02)\end{array}$ & $\begin{array}{c}-0.02 \\
(0.04)\end{array}$ & $\begin{array}{c}-0.03 * * \\
(0.01)\end{array}$ & $\begin{array}{c}-0.02 \\
(0.02)\end{array}$ & $\begin{array}{c}-0.04 \\
(0.05)\end{array}$ & $\begin{array}{c}-0.02 \\
(0.02)\end{array}$ & $\begin{array}{c}-0.01 \\
(0.04)\end{array}$ & $\begin{array}{c}0.16^{* * *} \\
(0.06)\end{array}$ \\
\hline Pollution intensity (latent) at interview & $\begin{array}{c}-0.02 \\
(0.02)\end{array}$ & $\begin{array}{c}-0.02 \\
(0.03)\end{array}$ & $\begin{array}{c}-0.02 \\
(0.03)\end{array}$ & $\begin{array}{l}0.03^{*} \\
(0.01)\end{array}$ & $\begin{array}{c}0.02 \\
(0.02)\end{array}$ & $\begin{array}{c}0.02 \\
(0.04)\end{array}$ & $\begin{array}{c}-0.01 \\
(0.01)\end{array}$ & $\begin{array}{c}0.02 \\
(0.02)\end{array}$ & $\begin{array}{c}-0.02 \\
(0.04)\end{array}$ & $\begin{array}{c}-0.03 * * * \\
(0.01)\end{array}$ & $\begin{array}{c}-0.01 \\
(0.02)\end{array}$ & $\begin{array}{c}-0.00 \\
(0.04)\end{array}$ & $\begin{array}{c}-0.03 \\
(0.02)\end{array}$ & $\begin{array}{c}-0.02 \\
(0.03)\end{array}$ & $\begin{array}{c}0.08 \\
(0.05)\end{array}$ \\
\hline Mean pollution at interview & $\begin{array}{c}-0.03 \\
(0.08)\end{array}$ & $\begin{array}{c}-0.12 \\
(0.13)\end{array}$ & $\begin{array}{c}0.02 \\
(0.19)\end{array}$ & $\begin{array}{c}0.00 \\
(0.00)\end{array}$ & $\begin{array}{c}0.00 \\
(0.00)\end{array}$ & $\begin{array}{c}0.00 \\
(0.00)\end{array}$ & $\begin{array}{c}-0.00 \\
(0.00)\end{array}$ & $\begin{array}{c}0.00 \\
(0.00)\end{array}$ & $\begin{array}{l}-0.00 \\
(0.00)\end{array}$ & $\begin{array}{l}-0.01 \\
(0.00)\end{array}$ & $\begin{array}{c}0.00 \\
(0.01)\end{array}$ & $\begin{array}{c}-0.00 \\
(0.03)\end{array}$ & $\begin{array}{l}-0.00 \\
(0.00)\end{array}$ & $\begin{array}{c}-0.00 \\
(0.00)\end{array}$ & $\begin{array}{c}0.02 \\
(0.02)\end{array}$ \\
\hline three-year mean & $\begin{array}{c}-0.11 \\
(0.08)\end{array}$ & $\begin{array}{c}-0.27^{*} \\
(0.14)\end{array}$ & $\begin{array}{l}-0.19 \\
(0.27)\end{array}$ & $\begin{array}{c}0.00 * * \\
(0.00)\end{array}$ & $\begin{array}{c}0.00 \\
(0.00)\end{array}$ & $\begin{array}{c}0.01 \\
(0.00)\end{array}$ & $\begin{array}{c}-0.00 \\
(0.00)\end{array}$ & $\begin{array}{c}0.00 \\
(0.00)\end{array}$ & $\begin{array}{l}-0.00^{*} \\
(0.00)\end{array}$ & $\begin{array}{c}-0.00 \\
(0.00)\end{array}$ & $\begin{array}{c}0.00 \\
(0.01)\end{array}$ & $\begin{array}{c}0.02 \\
(0.02)\end{array}$ & $\begin{array}{c}-0.00 \\
(0.00)\end{array}$ & $\begin{array}{c}-0.00 \\
(0.01)\end{array}$ & $\begin{array}{c}0.00 \\
(0.01)\end{array}$ \\
\hline \multicolumn{16}{|l|}{ Disorder } \\
\hline mean year pollution & $\begin{array}{c}0.04 \\
(0.11)\end{array}$ & $\begin{array}{c}-0.11 \\
(0.19)\end{array}$ & $\begin{array}{c}-0.22 \\
(0.25)\end{array}$ & $\begin{array}{c}0.00 * * \\
(0.00)\end{array}$ & $\begin{array}{c}0.00 \\
(0.00)\end{array}$ & $\begin{array}{c}0.01 * * \\
(0.00)\end{array}$ & $\begin{array}{c}0.00 \\
(0.00)\end{array}$ & $\begin{array}{c}0.00 \\
(0.00)\end{array}$ & $\begin{array}{c}-0.00 \\
(0.00)\end{array}$ & $\begin{array}{c}-0.00 \\
(0.01)\end{array}$ & $\begin{array}{c}-0.01 \\
(0.02)\end{array}$ & $\begin{array}{c}0.05^{* *} \\
(0.03)\end{array}$ & $\begin{array}{c}0.01 \\
(0.00)\end{array}$ & $\begin{array}{c}-0.00 \\
(0.01)\end{array}$ & $\begin{array}{c}-0.02 \\
(0.01)\end{array}$ \\
\hline Pollution intensity (latent) & $\begin{array}{c}0.02 \\
(0.02)\end{array}$ & $\begin{array}{c}-0.00 \\
(0.04)\end{array}$ & $\begin{array}{l}-0.01 \\
(0.06)\end{array}$ & $\begin{array}{c}0.07 * * * \\
(0.02)\end{array}$ & $\begin{array}{l}0.06^{*} \\
(0.03)\end{array}$ & $\begin{array}{c}0.03 \\
(0.06)\end{array}$ & $\begin{array}{c}0.01 \\
(0.02)\end{array}$ & $\begin{array}{c}0.04 \\
(0.03)\end{array}$ & $\begin{array}{c}-0.02 \\
(0.05)\end{array}$ & $\begin{array}{c}-0.01 \\
(0.02)\end{array}$ & $\begin{array}{c}-0.02 \\
(0.04)\end{array}$ & $\begin{array}{c}0.10 \\
(0.06)\end{array}$ & $\begin{array}{c}0.01 \\
(0.03)\end{array}$ & $\begin{array}{c}-0.02 \\
(0.04)\end{array}$ & $\begin{array}{c}-0.20^{* *} \\
(0.10)\end{array}$ \\
\hline
\end{tabular}




\begin{tabular}{|c|c|c|c|c|c|c|c|c|c|c|c|c|c|c|c|}
\hline $\begin{array}{r}\text { Pollution intensity (latent) at } \\
\text { interview }\end{array}$ & $\begin{array}{l}0.02 \\
(0.02)\end{array}$ & $\begin{array}{l}-0.01 \\
(0.04)\end{array}$ & $\begin{array}{l}-0.03 \\
(0.05)\end{array}$ & $\begin{array}{l}0.05^{* *} \\
(0.02)\end{array}$ & $\begin{array}{c}0.03 \\
(0.03)\end{array}$ & $\begin{array}{c}0.09 \\
(0.05)\end{array}$ & $\begin{array}{l}0.02 \\
(0.02)\end{array}$ & $\begin{array}{l}0.05 \\
(0.03)\end{array}$ & $\begin{array}{l}-0.04 \\
(0.05)\end{array}$ & $\begin{array}{l}-0.01 \\
(0.02)\end{array}$ & $\begin{array}{l}-0.01 \\
(0.04)\end{array}$ & $\begin{array}{l}0.11^{*} \\
(0.06)\end{array}$ & $\begin{array}{l}0.03 \\
(0.03)\end{array}$ & $\begin{array}{l}-0.01 \\
(0.04)\end{array}$ & $\begin{array}{l}-0.07 \\
(0.08)\end{array}$ \\
\hline three-years mean & $\begin{array}{c}0.03 \\
(0.11)\end{array}$ & $\begin{array}{l}-0.14 \\
(0.18)\end{array}$ & $\begin{array}{l}-0.15 \\
(0.27)\end{array}$ & $\begin{array}{c}0.01 * * * \\
(0.00)\end{array}$ & $\begin{array}{c}0.00 \\
(0.00)\end{array}$ & $\begin{array}{c}0.00 \\
(0.00)\end{array}$ & $\begin{array}{l}0.00 \\
(0.00)\end{array}$ & $\begin{array}{c}0.00 \\
(0.00)\end{array}$ & $\begin{array}{l}-0.00 \\
(0.00)\end{array}$ & $\begin{array}{l}-0.01 \\
(0.01)\end{array}$ & $\begin{array}{l}-0.01 \\
(0.02)\end{array}$ & $\begin{array}{c}0.02 \\
(0.02)\end{array}$ & $\begin{array}{l}0.00 \\
(0.00)\end{array}$ & $\begin{array}{l}-0.00 \\
(0.00)\end{array}$ & $\begin{array}{l}-0.01 \\
(0.01)\end{array}$ \\
\hline Mean pollution at interview & $\begin{array}{c}0.01 \\
(0.11)\end{array}$ & $\begin{array}{l}-0.24 \\
(0.20)\end{array}$ & $\begin{array}{l}-0.14 \\
(0.37)\end{array}$ & $\begin{array}{c}0.01 * * \\
(0.00)\end{array}$ & $\begin{array}{c}0.04 \\
(0.00)\end{array}$ & $\begin{array}{c}0.01 \\
(0.01)\end{array}$ & $\begin{array}{c}0.00 \\
(0.00)\end{array}$ & $\begin{array}{c}0.00 \\
(0.00)\end{array}$ & $\begin{array}{c}0.00 \\
(0.00)\end{array}$ & $\begin{array}{c}0.00 \\
(0.00)\end{array}$ & $\begin{array}{c}0.00 \\
(0.02)\end{array}$ & $\begin{array}{c}0.02 \\
(0.03)\end{array}$ & $\begin{array}{c}0.00 \\
(0.00)\end{array}$ & $\begin{array}{l}-0.00 \\
(0.01)\end{array}$ & \\
\hline
\end{tabular}

Source: SOEP 2002-2007: own calculations.

Note: Standard errors are in parenthesis. *indicates statistical significance at the $10 \%$ level, ** at the 5\% level, *** at the $1 \%$ level. All regressions include indicators for mother's

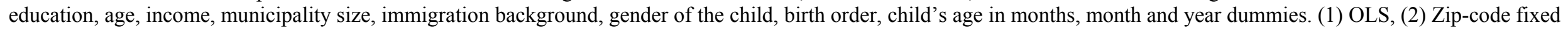
effect models, (3) Zip-code and family fixed effect models. Sample size varies between 629 and 775 observations. 
Table A7: Effects of outdoor and indoor pollution on child's health at two to three years of age (various model specifications)

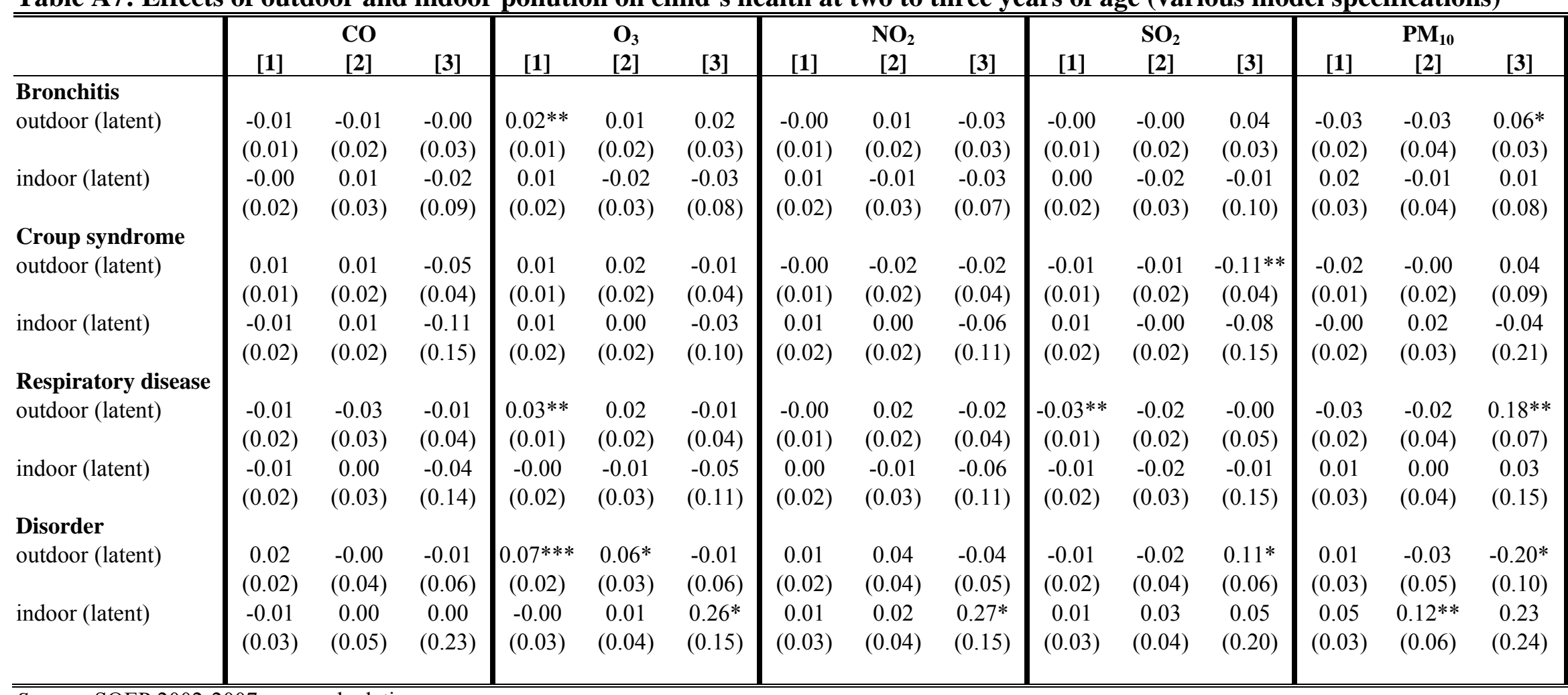

Source: SOEP 2002-2007: own calculations.

Note: Standard errors are in parenthesis. *indicates statistical significance at the $10 \%$ level, ** at the $5 \%$ level, *** at the $1 \%$ level. All regressions include indicators of mother's education, age, income, municipality size, immigration background, gender of the child, birth order, child's age in months, month and year dummies. Sample size varies between 629 and 775 observations. 
Table A8: Effects of indoor pollution on child's health at two to three years of age

\begin{tabular}{lccccc}
\hline \hline & & & & & \multicolumn{2}{c}{$\begin{array}{c}\text { Total number } \\
\text { of cigarettes } \\
\text { smoked }\end{array}$} \\
\hline Bronchitis & -0.01 & 0.01 & Mother & Father & \\
& $(0.03)$ & $(0.01)$ & $(0.03)$ & $(0.03)$ & $(0.00)$ \\
Croup & & & & & \\
syndrome & -0.01 & 0.00 & -0.00 & -0.00 & 0.00 \\
& $(0.03)$ & 0.00 & $(0.03)$ & $(0.02)$ & $(0.00)$ \\
Respiratory & -0.01 & $(0.03)$ & -0.01 & 0.00 & 0.00 \\
disease & $(0.03)$ & -0.00 & $(0.04)$ & $(0.03)$ & $(0.00)$ \\
Disorder & 0.03 & -0.03 & 0.04 & -0.04 & -0.00 \\
& $(0.05)$ & $(0.04)$ & $(0.05)$ & $(0.04)$ & $(0.00)$ \\
\hline \hline
\end{tabular}

Source: SOEP 2002-2007: own calculations.

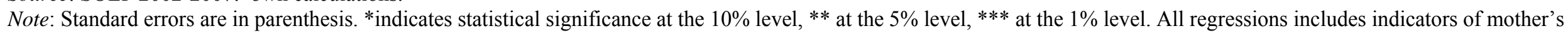
education, age, income, municipality size, immigration background, gender of the child, birth order and child's age in months. Sample size varies between 629 and 775

observations. 